\title{
Stratigraphic setting and timing of the Montagne d'Or deposit, a unique Rhyacian Au-rich VMS deposit of the Guiana Shield, French Guiana
}

\author{
James Guiraud $^{\mathrm{a}, *}$, Alain Tremblay ${ }^{\mathrm{a}}$, Michel Jébrak ${ }^{\mathrm{a}}$, Pierre-Simon Ross ${ }^{\mathrm{b}}$, Rock Lefrançois ${ }^{\mathrm{c}}$ \\ ${ }^{a}$ Université du Québec à Montréal, Département des Sciences de la Terre et de l'Atmosphère, C.P. 8888, Succ. Centre-ville, Montréal, QC H3C 3P8, Canada \\ ${ }^{\mathrm{b}}$ Institut national de la recherche scientifique, Centre Eau-Terre-Environnement, 490, rue de la Couronne, Québec, QC G1K 9A9, Canada \\ ${ }^{\mathrm{c}}$ Columbus Gold, 1090 Hamilton Street, Vancouver, BC V6B 2R9, Canada
}

\section{A R T I C L E I N F O}

Keywords:

Rhyacian

Montagne d'Or

Au-rich VMS

Geochronology

Transamazonian orogeny

Paramaca greenstone belt

\begin{abstract}
A B S T R A C T
In French Guiana, the Montagne d'Or gold deposit (5 Moz at $1.5 \mathrm{~g} / \mathrm{t} \mathrm{Au}$ ) is located in the northern branch of the Rhyacian Paramaca Greenstone Belt. The sulphide deposit is hosted by a south-facing bimodal volcanic and volcaniclastic sequence that is highly strained and affected by a penetrative E-W striking and steeply southdipping foliation.

The volcanic sequence is composed of three members, (1) the Lower unit in the stratigraphic footwall, (2) a bimodal mafic-felsic formation hosting the orebody, and (3) the Upper sedimentary and volcanic rocks unit in the stratigraphic hanging-wall. The bimodal formation is dominated by calc-alkaline felsic volcanic rocks in the west, interbedded/interdigitated with tholeiitic mafic rocks in the east. Pillowed mafic flows and graded-bedded felsic volcaniclastic rocks collectively indicate effusive to explosive volcanic activity in a submarine environment. The mineralization consists of thick and laterally extensive sulphide zones forming (1) stratiform sulphide disseminations, (2) structurally-transposed stringer stockworks, and (3) thin layers of deformed semi-massive sulphides. The gold-rich sulphide mineralization consists mainly of pyrite, pyrrhotite and chalcopyrite with minor sphalerite, magnetite, galena and arsenopyrite, hosted by chlorite-sericite-rich alteration zones mainly developed in the felsic tuff facies.

$\mathrm{U}-\mathrm{Pb}$ zircon geochronology shows that most of the Montagne d'Or volcanic and intrusive sequence has crystallized during a multi-cycle magmatic event, from ca. 2152 Ma to ca. 2130 Ma. A porphyry intrusion crosscutting the ore yields a U-Pb zircon age of $2117.6 \pm 5.1 \mathrm{Ma}$, hence constraining a minimum age for the auriferous sulphide mineralization. This also indicates that the sulphide mineralization was coeval with arc magmatism, demonstrating the volcanogenic nature of the Montagne d'Or gold deposit.
\end{abstract}

\section{Introduction}

Paleoproterozoic volcanic terranes are known for their high gold content in a variety of different deposits such as orogenic lode, Au-volcanogenic massive sulphide (VMS), porphyries, iron oxide copper gold deposits (IOCG) and paleo-placers (Poulsen, 2000; Groves et al., 2003; Dubé et al., 2007; Goldfarb et al., 2010). The Trans-Hudsonian and Svecofennian orogens are good examples of the diversity of gold occurrences in Paleoproterozoic greenstone belts (Franklin et al., 2005; Dubé et al., 2007; Mercier-Langevin et al., 2011; Hanski, 2015; Pehrsson et al., 2016). In the Rhyacian part of the northern Guiana Shield, Milési et al. (2003) recognized three types of primary gold deposits: (1) stratiform/stratabound gold-bearing tourmalinites, (2) mesothermal orogenic deposits along major faults/shear zones, and (3) paleoplacers (Fig. 1). Although only one occurrence of auriferous volcanogenic deposit was recognized in the Milési et al. (2003) synthesis (i.e.
Dorlin), numerous authors have suggested that the Guiana Shield presents a real potential for such type of gold mineralization (Gibbs and Barron, 1993; Sidder et al., 1995; Channer and Anderson, 2000). The Montagne d'Or gold deposit was the first volcanogenic and sulphide-rich deposit ever documented in the Guiana shield (Franklin et al., 2000). Its discovery has since been followed by the Serra do Ipitinga Au-Ag ( $\mathrm{Zn}-\mathrm{Cu}$ ) VMS deposit in Brazil (Fig. 1; Faraco et al., 2006; Klein et al., 2009), enhancing the potential of the Guiana shield for VMS deposits.

The local geological characteristics and genesis of VMS deposits of the northern Guiana Shield are, however, poorly-understood. In this contribution, we present a detailed stratigraphic and structural setting of the Montagne d'Or volcanic sequence and new U-Pb zircon ages highlighting the genetic connection between gold-sulphide mineralization and its volcanic framework.

\footnotetext{
* Corresponding author.

E-mail address: guiraud.james@courrier.uqam.ca (J. Guiraud).
} 


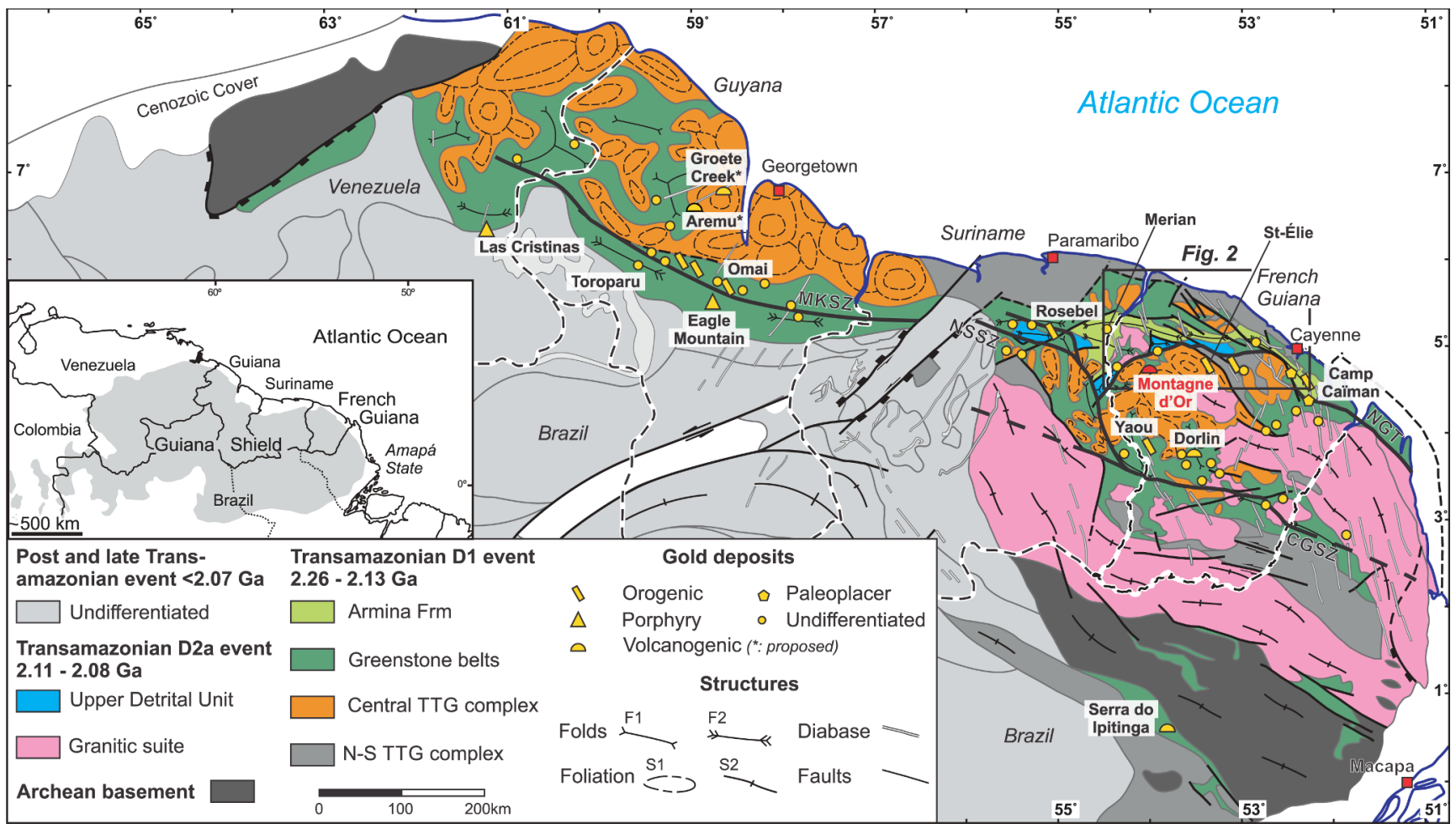

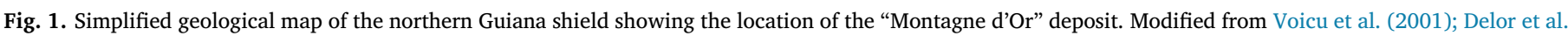

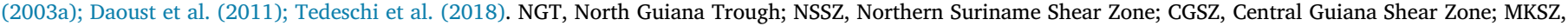
Makapa-Kuribrong Shear Zone. See text for details.

\section{Geological and tectonic setting of the northern Guiana Shield}

The Paleoproterozoic Guiana shield lies in northeastern South America (Fig. 1). It forms the basement of Guyana, Suriname, French Guiana, the southeastern half of Venezuela and part of northeastern Brazil. The geology of the Guiana Shield is poorly known, mainly due to difficult access, deep regolith covered by dense tropical rain forest and low topographic relief. Despite this, the geological knowledge of the northern Guiana Shield has increased with reviews by Gibbs and Barron (1993), Vanderhaeghe et al. (1998), Voicu et al. (2001), Delor et al. (2003a,b) and Kroonenberg et al. (2016). The stratigraphic and lithotectonic nomenclature used in this paper is from Delor et al. (2003a,b).

The northern Guiana Shield comprises four main tectono-stratigraphic domains (Fig. 1), from base to top: (1) the Archean Imataca Complex in Venezuela (Tassinari et al., 2004) and the Archean Amapá domain in Brazil (Avelar et al., 2003; Da Rosa-Costa et al., 2003, 2008); (2) the North and South TTG complexes, the major Central TTG complexes, along with the Paramaca volcanic Formation and overlying Armina Formation; (3) the Upper Detrital Unit, that formed along the North Guiana Trough and was coeval with a major granitic suite (ca. 2.1 to $2.08 \mathrm{Ga}$ ); and (4) late- to post-Transamazonian units such as granulites, widespread felsic volcanism/magmatism and minor sedimentary rocks, which have been arbitrary grouped for convenience on Fig. 1.

\subsection{Rhyacian events}

The Guiana Shield forms the northern part of the Amazonian craton (Gibbs and Barron, 1993). It has been proposed that it is the result of the tectonic collage of Paleoproterozoic terranes between the Archean Amazonian and Kénéma-Man provinces of Western Africa (Ledru et al., 1994; Vanderhaeghe et al., 1998; Delor et al., 2003a,b; Kroonenberg et al., 2016). Rocks of the Guiana Shield mainly formed by ocean spreading and arc magmatism, and accreted during the
Transamazonian orogeny. The latter is attributed to tectonic convergence between the Amazonian and West African cratons, and culminated with a plate collision that produced a series of greenstone belts, coeval tonalite-trondhjemite-granodiorite (TTG) belts, and subsequent granitic suite (Delor et al., 2003a, b). The Transamazonian orogeny is divided into two phases: (i) the Main Transamazonian event at 2.26 to $2.08 \mathrm{Ga}$ (D0, D1 and D2a), and (ii) the Late Transamazonian event between 2.07 and 1.93 Ga (D2b and a possibly D2c; Delor et al., 2003a,b). The latter event has been divided by Kroonenberg et al. (2016) into a 2.07 to $2.05 \mathrm{Ga}$ D2b and a third phase, D3, between 1.99 and $1.95 \mathrm{Ga}$.

The Main Transamazonian orogeny is related to a number of tectonic events including magmatic accretion, tectonic collage and crustal recycling (Vanderhaeghe et al., 1998; Delor et al., 2003a,b). The magmatic accretion started with the formation of a tholeiitic juvenile oceanic crust preserved in the "Ile de Cayenne" metamorphic complex (Milési et al., 1995; Vanderhaeghe et al., 1998). North-south convergence between the Amazonian and African cratons, accommodated by south-directed subduction, resulted in the formation of two TTGgreenstone magmatic arcs, (i) the high-grade, locally migmatized, North and South TTG complexes at 2.18-2.16 Ga and (ii) the Central TTG Complex at 2.15-2.13 Ga (also known as the "Complexe Guyanais"; Choubert, 1974), the latter forming a large plutonic complex surrounded by the Paramaca Greenstone Belts in central French Guiana (Delor et al., 2001; 2003b).

Volcanic rocks of the Paramaca Greenstone Belts (PGB) occupy two synclinoria that merge together westward in Suriname and extend eastward in Brazil (Choubert, 1974; Gibbs and Barron, 1993). From base to top, the stratigraphy of the PGB is as follows:

1. A lower sequence of tholeiitic basalts and gabbros, and amphibolitefacies equivalents, interlayered with komatiitic flows, the "Ile de Cayenne" Formation being interpreted as the metamorphosed equivalent of these rocks; 
2. 2.16-2.13 Ga calc-alkaline intrusive magmas feeding andesite to rhyolite flows and related tuffs, interlayered with greywackes, shales and carbonaceous ferruginous cherts of increasing proportion towards the top (Naipal and Kroonenberg, 2016);

3. The Armina Formation, a flysch-type sedimentary unit occurring at the top of the sequence, and consisting of interlayered fine-grained sandstone, greywacke and pelite with rare conglomerate forming a typical turbidite sequence.

The end of Transamazonian tectonism is marked by a transition from a compressive to transpressive deformation that is recorded by major structures such as the North Guiana Trough (Ledru et al., 1991; Egal et al., 1992; Vanderhaeghe et al., 1998), the Makapa-Kuribrong Shear Zone, the Central Guiana Shear Zone and the Northern Suriname Shear Zone (Voicu et al., 2001; Tedeschi et al., 2018), and by several pull-apart basins that formed between 2.11 and $2.08 \mathrm{Ga}$ along the North Guiana Trough, and which are filled by the Upper Detrital Unit (UDU) in French Guiana and the Rosebel Formation in Suriname (Milési et al., 1995; Delor et al., 2003a,b; Kroonenberg et al., 2016). U-Pb dating of detrital zircons from the Rosebel Formation (Daoust, 2016) suggests a maximum age of deposition of $2071 \pm 11$ Ma. The UDU unconformably overlies the PGB and is made up of conglomerates grading upward into interlayered fluvial sandstones, conglomerates and pelites (Bosma et al., 1983; Ledru et al., 1991; Egal et al., 1992; Vanderhaeghe et al., 1998; Daoust et al., 2011; Naipal and Kroonenberg, 2016). Regional-scale granitic plutonism also occurred during a 2.11-to-2.08 Ga tectonic event. These granites contain TTG and PGB xenoliths, attesting for crustal recycling and melting (Vanderhaeghe et al., 1998; Delor et al., 2001, 2003a,b).

In French Guiana, the late Transamazonian (D2b) is mainly marked by the emplacement ca. 2.07 to 2.06 Ga plutons and pegmatites along WNW-ESE dextral strike-slip shear-zones crosscutting the UDU (Delor et al., 2003a,b). The minimum age of deposition of the UDU is therefore constrained at ca. $2.06 \mathrm{Ga}$. Coeval to D2b, high-grade metamorphism is recorded in granulite belts between 2.07 and $2.05 \mathrm{Ga}$ but it is absent in French Guiana (see De Roever et al., 2003; Klaver et al., 2015; Kroonenberg et al., 2016).

\subsection{Rhyacian structural evolution and metamorphism in French Guiana}

Two major deformation phases have been recognized in French Guiana, D1 and D2 (Ledru et al., 1991; Milési et al., 1995; Vanderhaeghe et al., 1998), D2 possibly comprising two stages, D2a and D2b (Delor et al., 2003b).

Evidence for D1 is preserved in greenstone-TTG domains, in areas where D2 is absent or less penetrative. D1 is mainly expressed as a foliation that is more pronounced in metamorphic aureoles developed in greenstone belts wrapping around TTG batholiths. This foliation is subvertical and exhibits a down-dip mineral lineation defined by biotite and staurolite. D1 structures are intimately related to TTG emplacement, and shear-sense indicators suggest a vertical-sense of movement along intrusive contacts, with the relative uplifting of TTG as compared to adjacent greenstone belts (Delor et al., 2001, 2003b).

D2 structures are marked by a regional vertical foliation and subhorizontal mineral lineations, along with some folding. D2 is developed in the PGB and overlying sedimentary rocks of the Armina and Rosebel formations in which it is much more penetrative. D2 structures have been attributed to sinistral strike-slip deformation and oblique plate convergence (Marot, 1988; Ledru et al., 1991; Egal et al., 1992; Milési et al., 1995; Vanderhaeghe et al., 1998; Delor et al., 2001, 2003b). Strike-slip shear zones trend E-W, they are related to the formation of North Guiana Trough pull-apart basins and have been attributed to a D2a event (Ledru et al., 1991; Egal et al., 1992; Vanderhaeghe et al., 1998; Delor et al., 2003b). Migmatization of greenstone-TTG domains and emplacement of 2.1 to $2.08 \mathrm{Ga}$ anatectic granites also occurred during that D2a event (Milési et al., 1995; Delor et al., 2001, 2003b).
The D2b event is instead characterized by younger, WNW-ESE dextral shear zones along which 2.07 to 2.06 Ga monzogranites and pegmatites were emplaced (Delor et al., 2003b). A very late stage, D2c, has been locally proposed but its regional occurrence, if any, and significance are still debated (Milési and Picot, 1995; Delor et al., 2003b; Daoust et al., 2011; Daoust, 2016).

Two stages of metamorphism have been identified in French Guiana (Ledru et al., 1991; Milési et al., 1995; Vanderhaeghe et al., 1998; Delor et al., 2003b). Upper amphibolite facies assemblages, preserving a biotite-staurolite-andalusite paragenesis, are found around TTG batholiths and have been attributed to a D1 regional contact metamorphism. Both D1 and D2 are characterized by medium to low pressures (i.e. around $4 \mathrm{Kbar}$ ), suggesting moderate crustal thickening (Delor et al., 2003b).

\subsection{Post-transamazonian events in French Guiana}

They consist on the emplacement of various orientations and timing of dike swarms; NNE-SSW trending in the Paleoproterozoic ( $\geq 1.8 \mathrm{Ga}$ ), NW-SE trending in the Neoproterozoic (809 Ma) and WNW-ESE trending for the early Jurassic dykes population, the latter belonging to the Central Atlantic Magmatic Province (Deckart et al., 1997; Delor et al., 2003b; Nomade et al., 2007).

\section{3. .The Montagne d'Or deposit}

The Montagne d'Or deposit, belonging to the Paul-Isnard mining properties, is hosted by the northern branch of the PGB (Fig. 2). Rock units hosting the deposit are a bimodal volcanic sequence and associated sedimentary rocks, forming a $9 \mathrm{~km}$-long and $2 \mathrm{~km}$-wide inlier surrounded by TTG-type intrusive rocks (Fig. 2). Zircons extracted from a rhyolite within the bimodal volcanic sequence yielded a ${ }^{207} \mathrm{~Pb} /{ }^{206} \mathrm{~Pb}$ age of $2152 \pm 8 \mathrm{Ma}$ (Delor et al., 2003b). The precise location of the dated sample remains however unknown. The original stratification (bedding) of the Montagne d'Or volcanic sequence is transposed by the E-W trending, steeply south-dipping regional foliation that exhibits down-dip stretching and mineral lineations. The foliation is subparallel to the Chauve-Souris shear-zone, which more-or-less represents the southern limit of the Montagne d'Or volcanic sequence (Fig. 3). Regional metamorphism is at upper greenschist to lower amphibolite facies as attested by 1 ) retromorphosed andalusite crystals indicating low pressure conditions ( $<0.37 \mathrm{GPa}$ ), 2 ) chlorite dominating over biotite with local mutual replacement reactions, 3) recrystallized sulphides showing euhedral pyrite in a pyrrhotite cement, and 4) other metamorphic minerals such as garnet, sericite, epidote, actinolite and carbonates.

The Montagne d'Or mineralization consists of two zones of semimassive to stringer sulphides, the Lower Favorable Zone (LFZ) and the Upper Favorable Zone (UFZ), and of two subsidiary sulphide-rich horizons known as the Footwall Zone (FWZ) and the Hanging-Wall Zone (HWZ), both marked by stratabound sulphide disseminations, stockworks-veinlets and transposed layers of semi-massive sulphides. The gold-rich sulphide mineralization consists mainly of pyrite, pyrrhotite and chalcopyrite with minor sphalerite, magnetite, galena and arsenopyrite hosted in chlorite-sericite-rich alteration zones (Franklin et al., 2000). On the basis of grade and tonnage (i.e. $1.5 \mathrm{~g} / \mathrm{t} \mathrm{Au}$ and $105 \mathrm{t}$ Au resources), the Montagne d'Or deposit belongs to the 'anomalous' VMS field of the Mercier-Langevin et al. (2011) classification. However, we informally consider Montagne d'Or as an Au-rich VMS deposit, mainly because gold is the single economic commodity to be exploited, without any significant contribution from base metals.

\subsection{Stratigraphy}

The Montagne d'Or volcanic sequence consists of three parts, from base to top (Figs. 3 and 4): (1) a lower (footwall) unit overlain by (2) a 


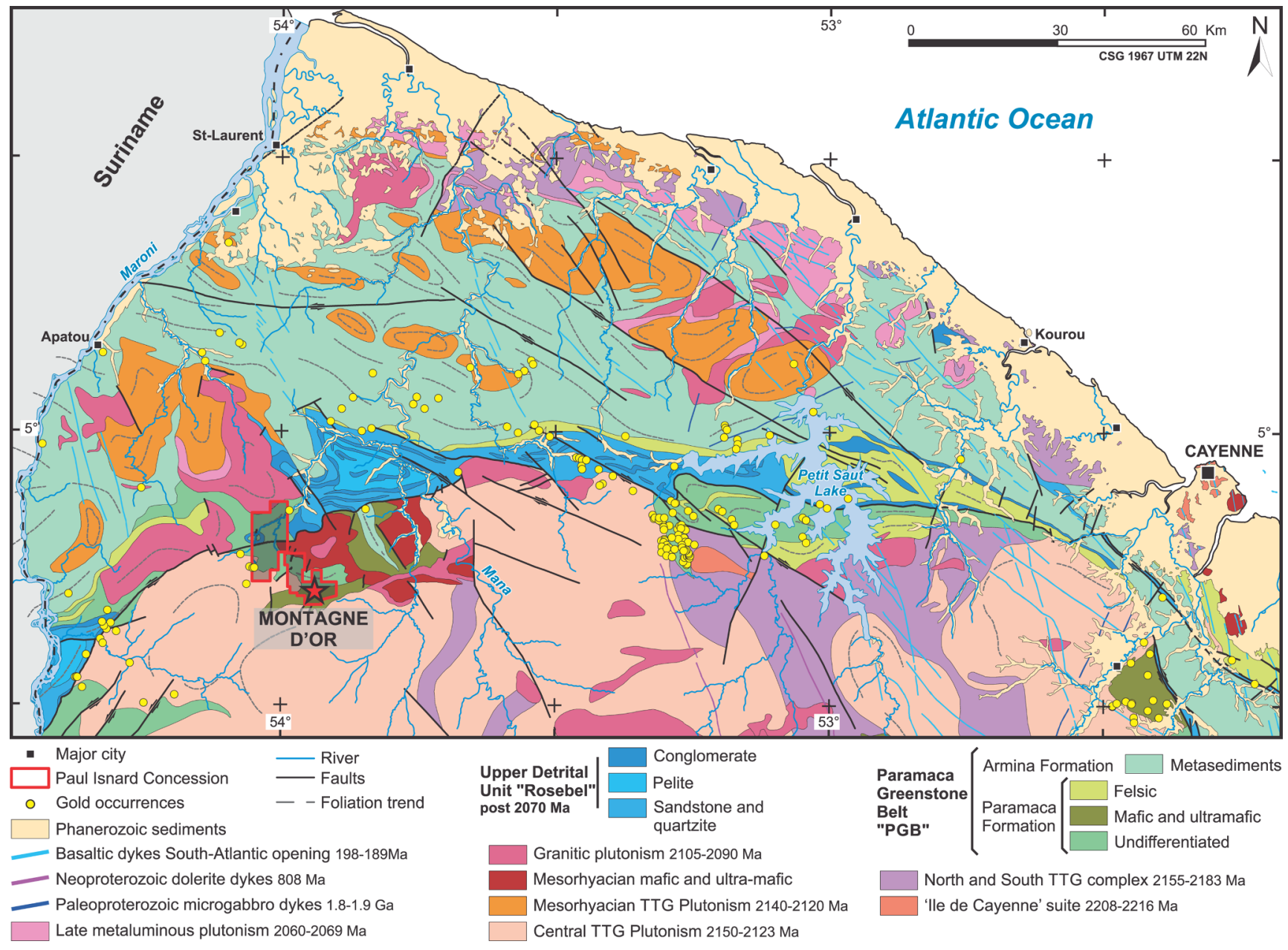

Fig. 2. Geological map of the northern branch of the Rhyacian Paramaca Greenstone Belt and adjacent TTG complexes in French Guiana with location of the Montagne d'Or deposit. Modified from Delor et al. (2003b). See Fig. 1 for location.

bimodal volcanic unit comprising the central mafic flows of tholeiitic affinity in the eastern part of the property, interdigitated with the central felsic unit of calc-alkaline affinity in the west, and (3) an upper sequence of interbedded sedimentary and volcanic rocks. Based on graded beds observed in felsic rocks, the Montagne d'Or sequence is considered to be south-facing (Franklin et al., 2000). The volcanic rocks are intruded by syn- to post-volcanic intrusions, whereas both the volcanic and sedimentary lithologies are intruded by ENE trending synto late-tectonic diabase dikes.

\subsubsection{Lower unit}

The lower volcanic sequence comprises mafic volcanic and reworked volcaniclastic rocks that constitute the footwall of the gold mineralization. Northward, this sequence is bounded by a foliated tonalite. The exact nature of the contact between the tonalite and the volcanic rocks is unknown but, based on its geophysical characteristics (Thomas, 2014), it most likely corresponds to a fault marked by a low magnetic signature.

This Lower unit comprises a heterogeneous assemblage of bedded mafic tuffs, mudstones and reworked volcaniclastic rocks. Aphanitic and massive mafic volcanic flows are also locally present, interlayered within the volcaniclastic and sedimentary sequence. The distinction between bedded mafic tuffs and mudstones is, however, sometimes difficult due to similar textures, colors and composition. Sedimentary rocks are characterized by $\mathrm{cm}$-thick layers of chlorite-epidote in mudstone (Fig. 5C), which are more abundant towards the base and the top of the Lower unit. Towards the top, a series of $\mathrm{cm}$ - to metre-thick layers of graphitic mudstones occur and represent important marker horizons that are easily traceable by electro-magnetic geophysical surveys.

The central part of the Lower unit consists of thinly-bedded mafic tuffs characterized by variable amounts of chlorite, amphibole, epidote, quartz and calcite. These are overlain by aphanitic mafic volcanic flows. Reworked volcaniclastic rocks and mixed volcanic and sedimentary rocks also occur. Some of these sedimentary rocks are greywackes, showing fragmented quartz-plagioclase crystals and chert clasts within a biotite-amphibole-clinozoisite matrix (Fig. 5A and G). The reworked volcaniclastic rocks are composed of felsic lithic lapilli and pumices in a mafic tuffaceous or a fine-grained greywacke matrix (Fig. 5B). These volcaniclastic rocks locally show well-preserved graded-bedding structures (Fig. 5A and B). A weakly-developed chlorite-rich or epidoteclinozoisite-calcite alteration is observed.

\subsubsection{Central mafic flow unit}

The Central Mafic Flow (CMF) unit is part of the bimodal volcanic formation. It hosts a minor part of the Montagne d'Or deposit (Fig. 3). It comprises mafic pillowed and sheet flows with thin interflows of mafic tuff. Felsic tuffs are sometimes found in the interflow material and are the host lithologies of the UFZ and LFZ ore zones (Franklin et al., 2000). Post-volcanic dark QFP, intermediate intrusions and late diabase dikes crosscut these rocks.

The massive volcanic flows are characterized by a homogeneous greenish, aphanitic to microcrystalline matrix cut by chlorite-rich veinlets and abundant veins of quartz-calcite-epidote-chlorite. The core of volcanic flows is locally coarse-grained, showing $\mathrm{mm}$-scale 


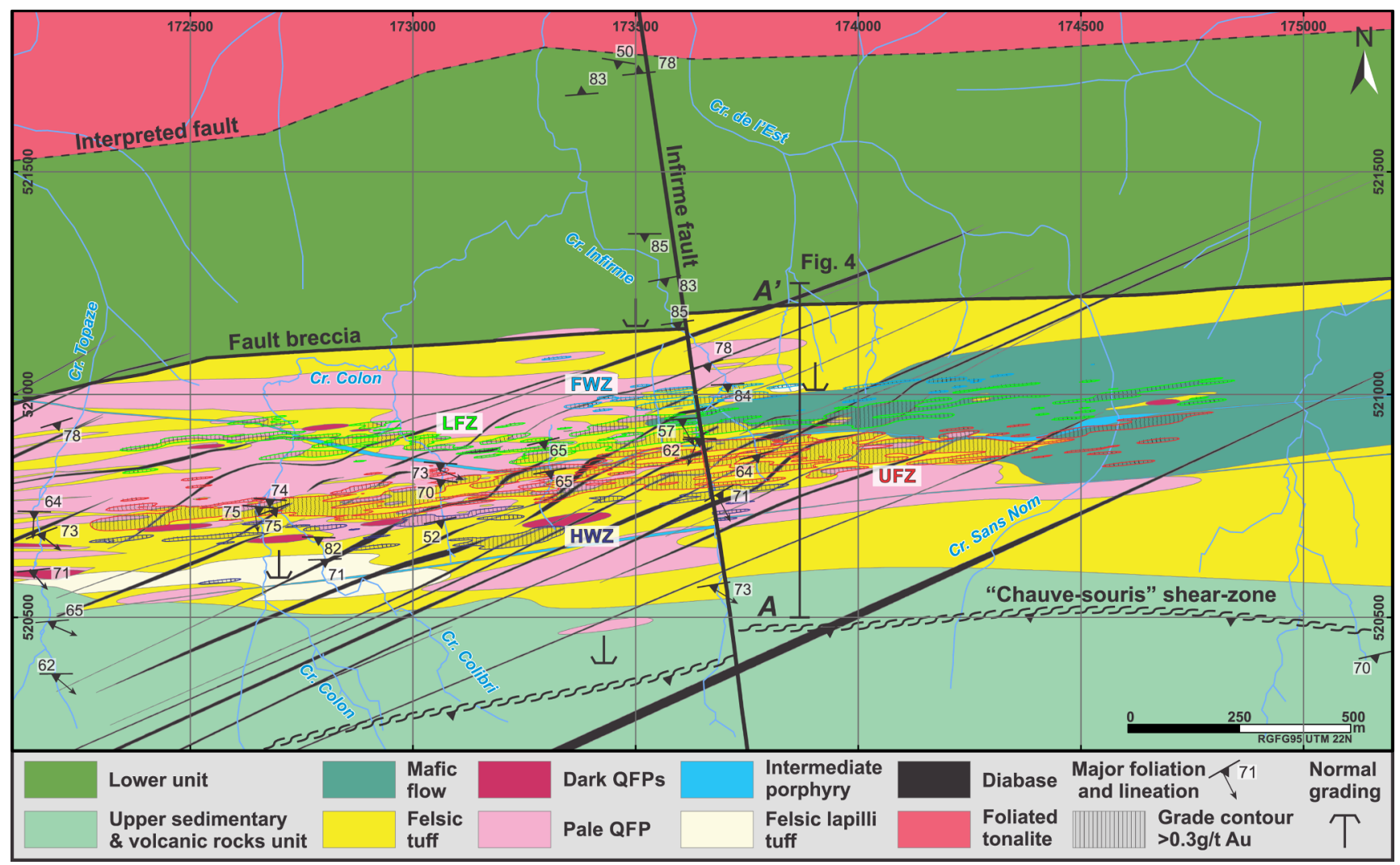

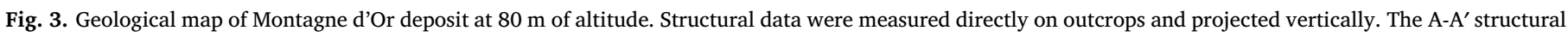

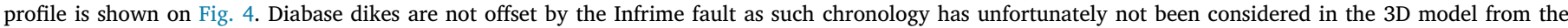

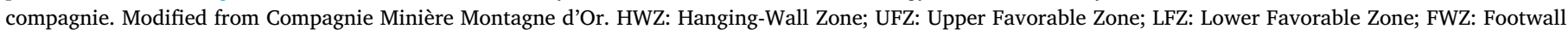
Zone.

hornblende crystals giving a pseudo-perlitic texture to the rock.

In pillowed flows, pillow margins show 1-to-4 mm-wide stretched amygdales (Fig. 6A), filled by epidote, chlorite, hornblende, quartz and sometimes sulphide minerals (Fig. 6B). The inter-pillow hyaloclastic material has recrystallized to hornblende, actinote, epidote and disseminated pyrite and chalcopyrite within a chlorite-rich and finegrained matrix (Fig. 6A).

Mafic tuffs of the CMF unit are heterogeneous but usually show millimetric to centimetric laminations and thin beds, with variable amounts of chlorite, amphibole, magnetite, feldspar, quartz and carbonates. Similar banding of tectonic origin, representing pseudo-tuffs, due to transposition of veinlets and alteration haloes within dark green, fine-grained to aphanitic mafic rocks locally occurs.

Pervasively altered and mineralized rocks, locally known as the "hyperchlorite" facies, are devoid of primary minerals and textures and totally made up of hydrothermal minerals such as chlorite, biotite, quartz, sulphides, magnetite and sericite. The "hyperchlorite" facies is best developed in mafic tuff horizons of the CMF unit and contains semi-massive, cm- to metre-thick bands of sulphides locally related to felsic tuffs and dark QFP intervals. The mineralization comprises euhedral pyrite, magnetite and chalcopyrite in pyrrhotite matrix with electrum inclusions. Sphalerite, galena and arsenopyrite are minor components. The most intensively chloritized parts of that facies contain $\mathrm{mm}$ - to $\mathrm{cm}$-size porphyroblasts of garnet and rare andalusite crystals retromorphosed into a quartz-sericite assemblage.

In the western part of the Montagne d'Or deposit, the CMF unit defines a single mafic interval bounded by felsic lapilli tuff. This mafic horizon is heterogeneous and consists of variably altered and mineralized massive flow and mafic tuff. The tuffs contain detrital grains of quartz, which are however more abundant in mafic lapilli tuffs with siliceous pumice and felsic clasts (Fig. 6C). This mafic horizon, characterized by felsic detritus, suggests mixing during its emplacement within the surrounding felsic lapilli tuffs.

\subsubsection{Central felsic unit}

Felsic rocks are predominant on the western side of the Montagne d'Or property and host most of the gold mineralization. The Central Felsic (CF) unit consists of four types of intrusive and extrusive lithologies: (1) homogeneous pale-colored quartz-feldspar porphyritic (QFP) subvolcanic intrusions, (2) dark quartz-feldspar porphyritic (QFP) intrusions, probably sills, cutting the whole sequence, (3) quartz-bearing and altered felsic tuffs hosting the sulphide mineralization, and (4) felsic lapilli tuffs.

Pale QFP. The pale QFP facies consists of 15-30\% quartz-plagioclase phenocrysts in a grey-to-white, siliceous microcrystalline groundmass (Fig. 6D). It is homogeneous in composition and size of phenocrysts. Plagioclase is euhedral, 1 to $3 \mathrm{~mm}$-wide, and are weakly stretched and altered. Quartz phenocrysts are less abundant than plagioclase, 1 to $4 \mathrm{~mm}$ in diameter, and show rounded and corroded crystal faces. Flakes of biotite are locally abundant (Fig. 6E). The pale QFP facies can be several tens of metres-thick, particularly in the western part of the deposit where it constitutes a predominant rock facies. It is commonly in sharp contact with felsic tuff (Fig. 6D-E), although contacts are frequently overprinted by pervasive alteration and a penetrative schistosity. Metres-thick rafts of felsic tuff are locally found within the pale QFP. Towards the base of the CF unit, the pale QFP facies consists of a monomict, clast-supported breccia, showing angular and blocky jigsawfit textures in a chlorite-rich matrix (Fig. 6F), a texture that is possibly related to hydrothermal brecciation. Hydrothermal alteration is only weakly developed in the pale QFP facies and is marked by the transformation of plagioclase into sericite. The pale QFP is barren in terms of sulphide mineralization. It is interpreted as a shallow subvolcanic 


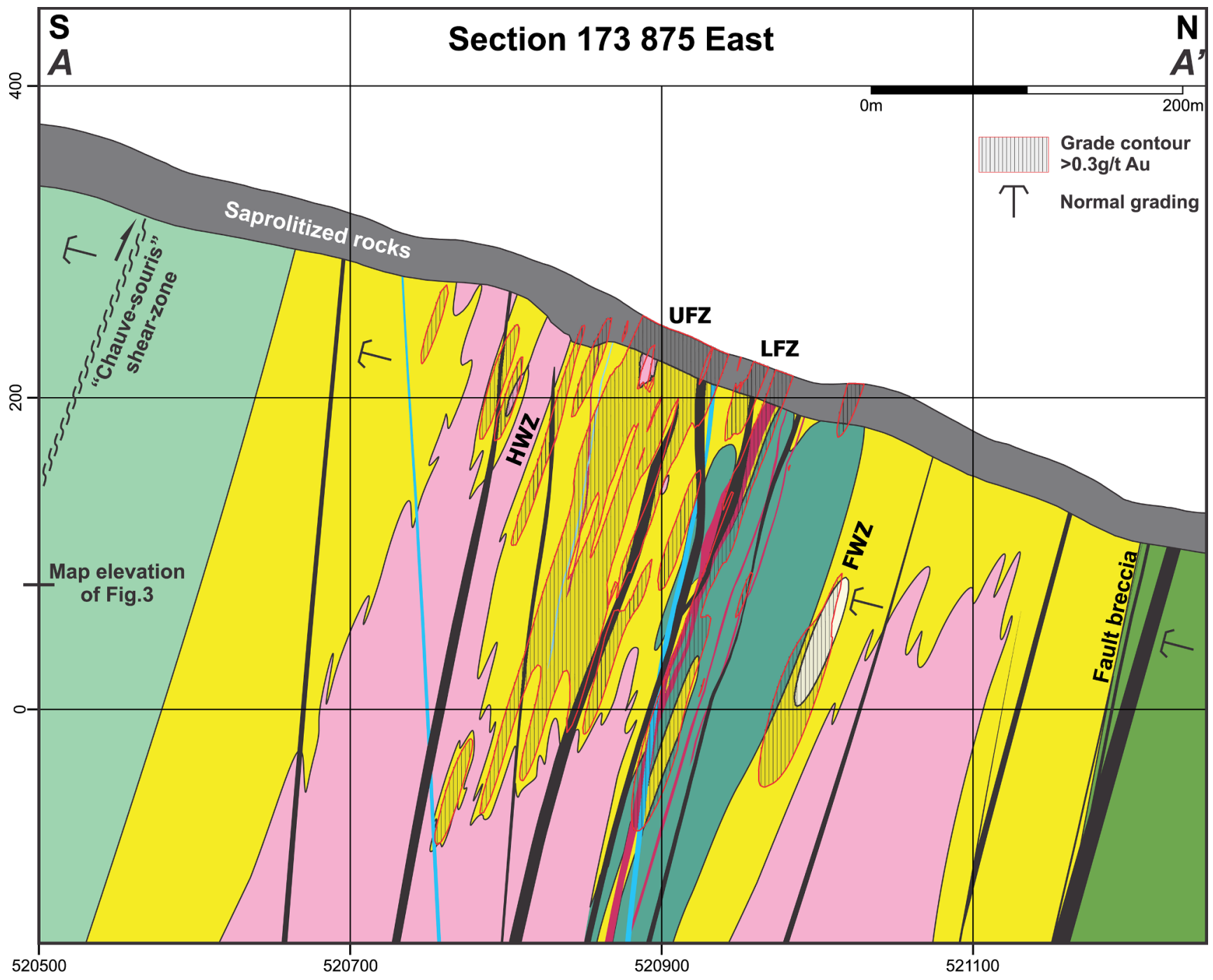

Fig. 4. Structural profile across the central part of the Montagne d'Or deposit. See Fig. 3 for location and symbols explanation.

intrusive complex within the tuffs and lapilli tuffs of the Central Felsic unit. Deformation is subdued in that facies where it is essentially marked by a weakly-developed schistosity and stretching of plagioclase phenocrysts.

Dark QFP. Dark QFP intrusions are characterized by a dark-grey microcrystalline to aphanitic groundmass (Fig. 7A and B). The typical lithology contains $5-10 \%$ of $2-7 \mathrm{~mm}$, blueish euhedral quartz phenocrysts and $10-20 \%$ of $1-5 \mathrm{~mm}$-wide euhedral plagioclase crystals. Plagioclase phenocrysts are sometimes zoned. Biotite lenses of $5 \mathrm{~mm}$ to $1 \mathrm{~cm}$-long commonly occur (Fig. 7A and B). These dark QFPs crosscut both the CMF and the CF units. Some dark QFP intrusions are even found in the Upper sedimentary and volcanic rocks unit. The dark QFPs locally form a swarm of intrusions in the CF unit. These intrusions are $20 \mathrm{~cm}$ - to $10 \mathrm{~m}$-thick. The contact with surrounding lithologies is sharp and, in most cases, subparallel to the regional schistosity and/or bedding due to transposition. The dark QFPs show zones of hydrothermal alteration marked by the transformation of plagioclase into sericite and by the chloritization of the groundmass. The alteration often coincides with corridors of penetrative deformation marked by a pervasive development of the schistosity and noticeable mineral stretching. Disseminations of pyrite and pyrrhotite are associated with these deformation/alteration zones. The dark QFPs are interpreted as the latest stage of the Montagne d'Or felsic volcanism.

Felsic tuffs. The felsic tuff facies is made up of $1-20 \%$ blue quartz and rare plagioclase crystals in an aphanitic matrix. Quartz crystals vary between $<0.5$ and $5 \mathrm{~mm}$ in diameter. They are rounded to slightly stretched, sometimes euhedral where deformation is less intense. Variations in the abundance and size of quartz grains define $20 \mathrm{~cm}$ to $4 \mathrm{~m}$-thick beds that range from coarse to fine-grained tuff (Ross, 2014). Some of these beds preserve normal grading, indicating southward younging directions. The matrix of these tuffs is usually greyish in the absence of hydrothermal alteration, whereas altered felsic tuffs display different colors, (i) light-blue to bluish and silky glint by sericitechlorite alteration; (ii) light-grey to beige and intense silky glint by sericite alteration (Fig. 6D and E); and (iii) bleached beige-grey to white by sericite-silica alteration. In these rocks, gold mineralization is related to semi-massive or/and stringer sulphides. Pyrite is the predominant sulphide mineral followed by pyrrhotite and chalcopyrite with local sphalerite, arsenopyrite, magnetite and galena assemblages. Chalcopyrite is usually associated with the highest gold values. Gold mostly occurs as electrum around sulphides and rare inclusions in pyrite. This felsic tuff facies is commonly strongly foliated, marked by sericite layers and recrystallized quartz laminae (Fig. 6E). The bedding is usually transposed into the foliation which exhibits pressure shadows, intrafolial folds, durchbewegung and piercement textures.

Felsic lapilli tuffs. The felsic lapilli tuff facies is intercalated within the tuff beds in two occurrences: one at the stratigraphic base of CF unit just below the CMF unit, and a thicker one near the stratigraphic top of the CF unit (Figs. 3, 4). The lower occurrence remains under-investigated, as it has been encountered only in few drill holes reaching 

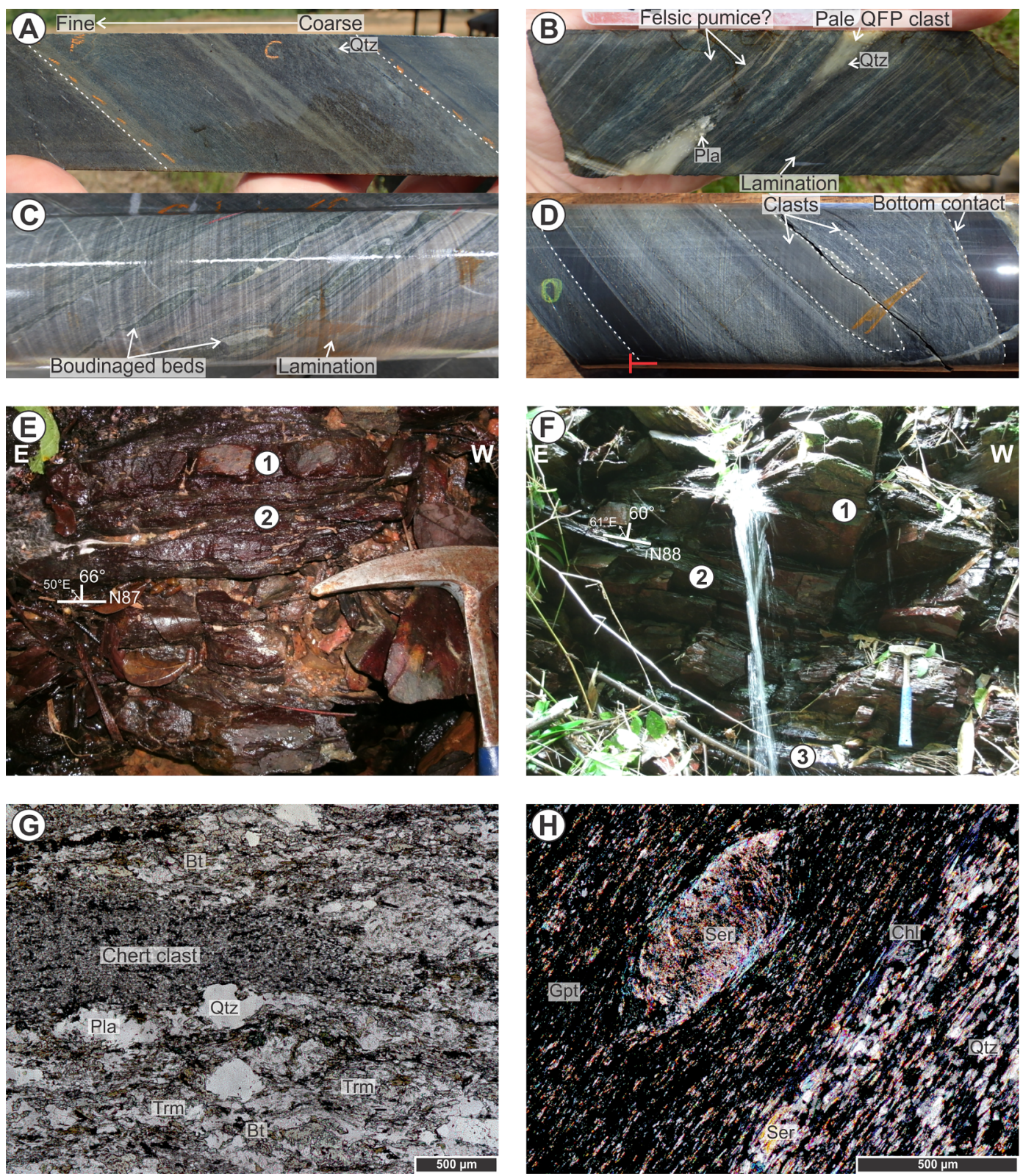

Fig. 5. Lower unit (photos $A$ to $C$ and G) and Upper sedimentary and volcanic rocks unit (photos D to F and H). (A) South facing graded-bed in a reworked volcaniclastic core sample (MO97030, 170.2 m). (B) Mafic laminated sedimentary rock showing pale QFP clasts and felsic pumices (MO9818, 132.10 m). (C) Thin beds of alternating cherty mudstone and mafic tuff showing local boudinage (CO15007, $71.10 \mathrm{~m}$ ). (D) South-facing, clast-bearing graded beds of turbiditic sandstone (GT01, 49-55.7 m). (E) Outcrop of sedimentary rocks of the Topaze creek showing greywacke beds (1) and mudstone (2). Hammer head for scale. (F) Outcrop of sedimentary rocks of the Topaze creek showing an example of interbedded cherty (1) and massive greywackes (2) and pelitic and graphitic schist layers (3) at the bottom. Hammer for scale. (G) Photomicrograph of a chert clast in reworked volcaniclastic facies of the Lower unit. Plane-polarized light (MO97030, $172.7 \mathrm{~m}$ ). (H) Photomicrograph of a retromorphosed andalusite porphyroblast in a graphitic mudstone of the USVR. Cross-polarized light (GT03, $101.1 \mathrm{~m}$ ). Scales for photos A to C are half NQ cores ( $4.77 \mathrm{~cm}$ diameter) whereas scale for photo $\mathrm{D}$ is the half $\mathrm{HQ}$ core $(6.3 \mathrm{~cm}$ diameter).

the Footwall Zone. It seems to have a relatively short lateral extension and quickly disappears westward. This lower occurrence has a thickness of tens of metres and shows south-facing graded beds. It is heterogeneous and characterized by the presence of mafic lithic clasts mixed with felsic lapilli (Fig. 7E).

The upper occurrence of the felsic lapilli tuff beds (Figs. 6C, 7C) is in the western part of the Montagne d'Or deposit. It is tens of metres thick and extends laterally for one kilometre along the Hanging-Wall Zone; lapilli tuff beds are up to $4 \mathrm{~m}$-thick and characterized by abundant south-facing graded beds (Fig. 8).

Three types of clasts are found in the felsic lapilli tuffs. The most abundant type of clasts contains quartz and plagioclase phenocrysts in a white to beige groundmass (Fig. 7C and E). These clasts are mostly angular to sub-angular, some of them are stretched due to deformation, and they have sizes varying from 1 to $4 \mathrm{~cm}$-long (Fig. 8). We consider that they are juvenile clasts (White and Houghton, 2006) due to their abundance and textural resemblance to the pale QFP intrusions. Such clasts are also found in reworked volcaniclastic flows of the Lower unit and, more rarely, as lithic clasts in the mafic tuff facies of the CMF unit. The second type consists of aphyric to sparsely quartz-phyric, flattened and stretched clasts, varying between 1 and $4 \mathrm{~cm}$-long and 1 to $5 \mathrm{~mm}$ thick. The groundmass is interpreted as formerly glassy, but is now typically altered to sericite. We interpret these clasts as pumice (Fig. 7C and D). Strong deformation frequently makes their recognition difficult. Some pumice fragments are coated by a pyritic shell and vesicles filled by pyrite-magnetite-epidote-chlorite (Fig. 7D). The last and less 

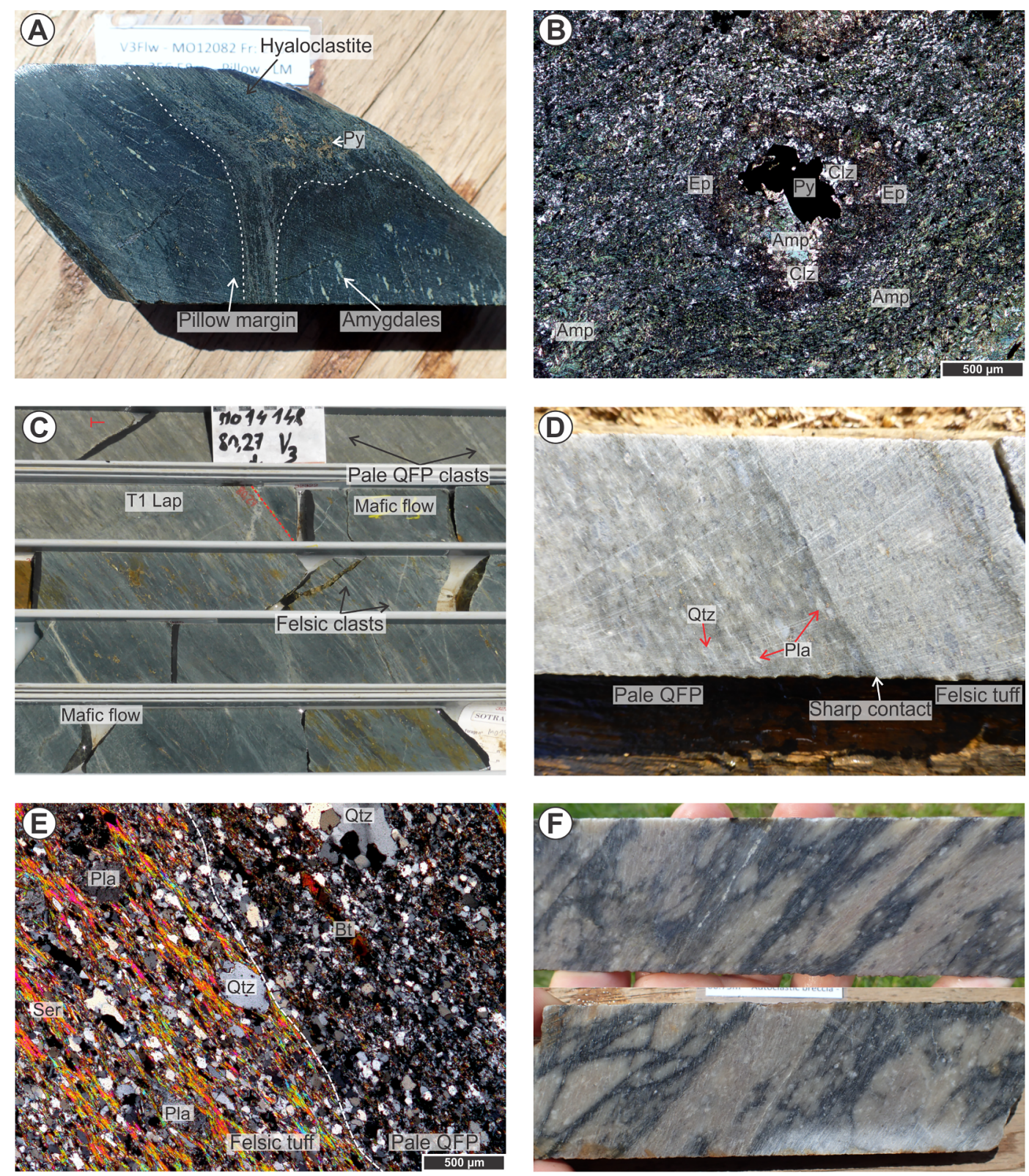

Fig. 6. Central mafic flow unit (photos A to C) and Central felsic unit (photos D to F). All photos of drill cores show half NQ cores of $4.77 \mathrm{~cm}$ in diameter. (A) Interpillow material made up of mineralized hyaloclastite with pyrite dissemination, the pillow border is marked by chilled margins and amygdales in the inner part (MO12082, $256.5 \mathrm{~m}$ ). (B) Photomicrograph of an amygdale filled by pyrite in the core, surrounded by a mixture of epidote, clinozoisite and amphibole. Crosspolarized light (MO12082, $263.1 \mathrm{~m}$ ). (C) Drill core section of a mafic interval showing a clastic part with felsic clasts, and interlayered felsic lapilli tuffs (MO14148, 74-87.8 m). (D) Sharp contact between the pale QFP and a felsic tuff (MO14164, $251 \mathrm{~m}$ ). (E) Photomicrograph of the pale QFP/felsic tuff contact. The pale QFP contains biotite crystals within a fine-grained quartz matrix which contrasts with the coarser, quartz and sericite-rich matrix of the felsic tuff. Cross-polarized light (MO14164, $253.7 \mathrm{~m}$ ). (F) Peperite or hydrothermal breccia in a pale QFP marked by abundant blocky clasts, jigsaw-fit texture and sparse matrix, principally composed of chlorite (MO98018, 65-67 m).

abundant type of clasts consist of black mafic fragments (Fig. 7E), and are found only in the lowermost occurrence of felsic lapilli tuffs. These clasts are cm-long, subangular and comprise small crystals of biotite, pyrite and epidote (Fig. 7F).

Within graded beds of lapilli tuffs, the base contains $\mathrm{cm}$-scale pale QFP lapilli that decrease in size and abundance toward the top. The middle part of the beds contains rare pumice clasts whereas the top consists of coarse to fine-grained tuff (Fig. 8). Sulphide mineralization, alteration and deformation are much more developed in the finergrained parts of beds, suggesting a more reactive behavior of this material with hydrothermal fluids.

\subsubsection{Tuffite horizon of the lower favorable zone (LFZ)}

The upper part of the LFZ is marked by a mafic rock unit characterized by a specific geochemical signature. It corresponds to "high $\mathrm{Ni}$ " samples identified as mafic tuff and hyperchloritic felsic rocks by Franklin et al. (2000). It is here identified as a tuffite horizon composed of a dark-green to black microcrystalline assemblage of actinolite, biotite, and chlorite with abundant euhedral crystals of apatite (Fig. 9A and $\mathrm{C}$ ). Aggregates of actinote, clinozoisite, and clinozoisite-plagioclase-carbonate also occur (Fig. 9C) and are interpreted as remnants of clasts and/or infillings of original pore space. The tuffite facies is currently highly porous due to carbonate dissolution. It is 1 to $2 \mathrm{~m}$-thick and is crosscut by pale QFP intrusions (Fig. 9B) and a thick, continuous and distinct dark QFP intrusion; cm-scale tuffite clasts occur as 

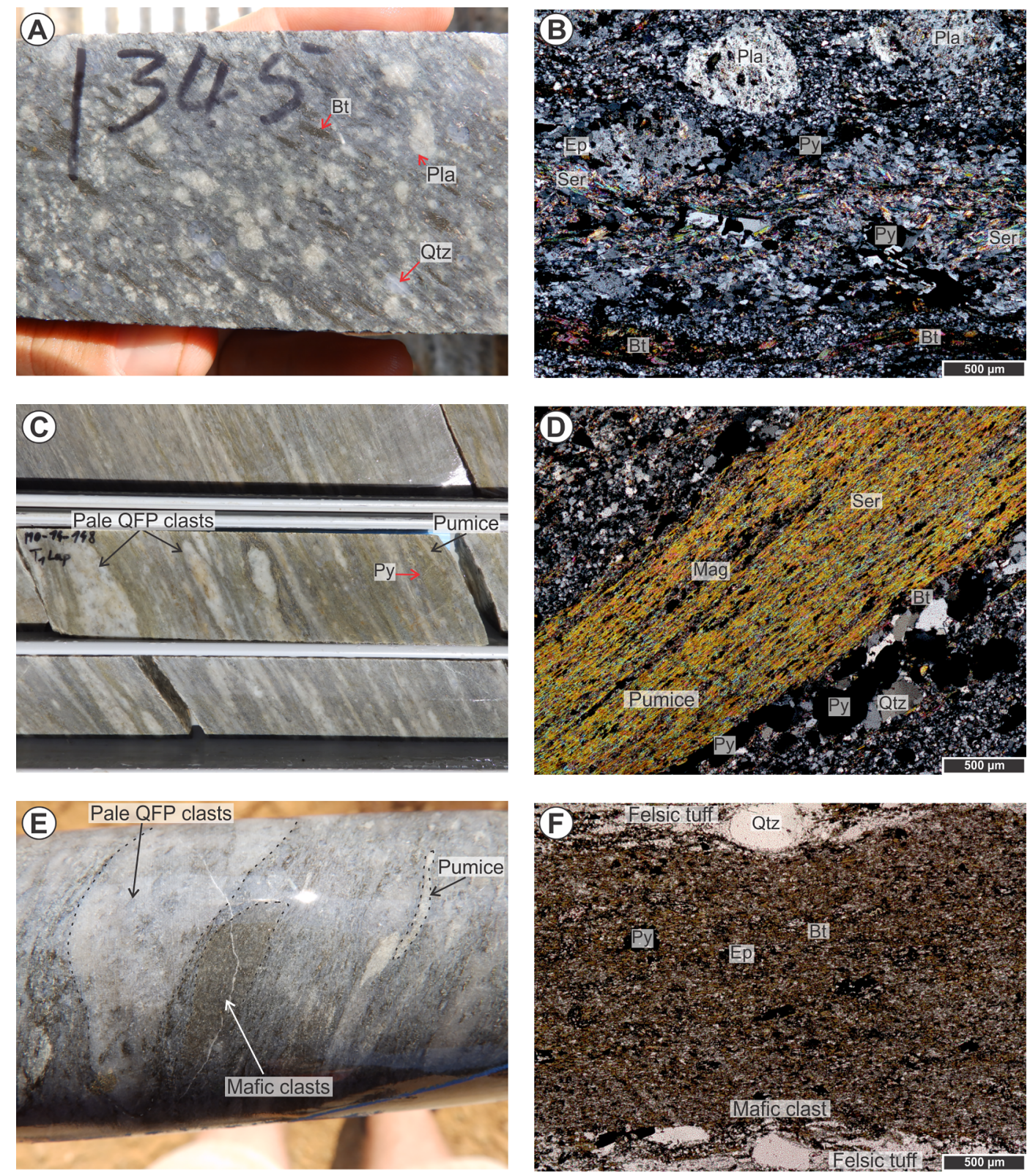

Fig. 7. The Central felsic unit facies. All photos of core samples show half NQ cores of $4.77 \mathrm{~cm}$ in diameter. (A) Dark QFP with plagioclase, blue quartz and biotite phenocrysts (MO12072, 345 m). (B) Photomicrograph of the dark QFP showing a very fine-grained quartz-rich groundmass hosting euhedral plagioclase phenocrysts. Cross-polarized light (MO14142, $119.6 \mathrm{~m}$ ). (C) Lapilli tuff with two types of juvenile lapilli, i.e. pale QFP and possible pumice clasts, surrounded by disseminated pyrite (MO14148, $90.5 \mathrm{~m}$ ). (D) Photomicrograph of a possible pumice altered to sericite, with pyrite shell and disseminations of magnetite and titanite. Crosspolarized light (MO12092, $111.3 \mathrm{~m}$ ). (E) Polymictic felsic lapilli tuff with pale QFP lapilli, mafic lithic lapilli and possible pumice (MO14185, $313 \mathrm{~m}$ ). (F) Photomicrograph of a mafic clast showing fine needles of biotite in an epidote-pyrite groundmass, within the felsic lapilli tuff facies. Plane-polarized light (MO14185, $316.7 \mathrm{~m})$.

xenoliths within several of these intrusions (Fig. 9B). The tuffite displays a 10 to $20 \mathrm{~cm}$-thick skarn-like reaction aureole of biotite and epidote, sometimes enriched in carbonate-clinozoisite-pyrite-actinote, at the contact with crosscutting intrusive rocks (Fig. 9B). It is often mineralized with up to $10 \%$ pyrite and minor magnetite. The sulphide mineralization varies from barren to gold-rich and possibly marks the proximity of gold-copper-rich zones of the LFZ that occur a few metres stratigraphically below. Pyrite forms centimetric layers or $2-3 \mathrm{~mm}$ euhedral disseminated crystals (Fig. 9A and B). The tuffite horizon is continuous along the strike of the LFZ, at least in the western part of the Montagne d'Or deposit, it is interpreted as a mixture of mafic volcanic ashes, marine sedimentary precipitation and exhalative material. Such an origin is suggested by: (1) thin sulphide-rich layering, (2) the heterogeneous character of this horizon with remnants of clasts and/or original pore spaces, (3) abundant sulphides, apatite and carbonates with alteration and mineralization products consistent with a highly porous behavior, (4) its along-strike continuity, and (5) the presence of crosscutting syn- and post-volcanic intrusive rocks.

\subsubsection{Upper sedimentary and volcanic rock unit}

The uppermost portion of the Montagne d'Or sequence consists of alternating sedimentary and volcanic rocks in sharp contact with the underlying CF unit. This Upper Sedimentary and Volcanic Rocks unit (USVR) is at least 1-2 km thick (Fig. 3).

The lower part of the USVR comprises sedimentary rocks, mafic tuff layers and rare mafic lavas. The sedimentary rocks are well-layered 


\section{Simplified log of ddh MO12098}

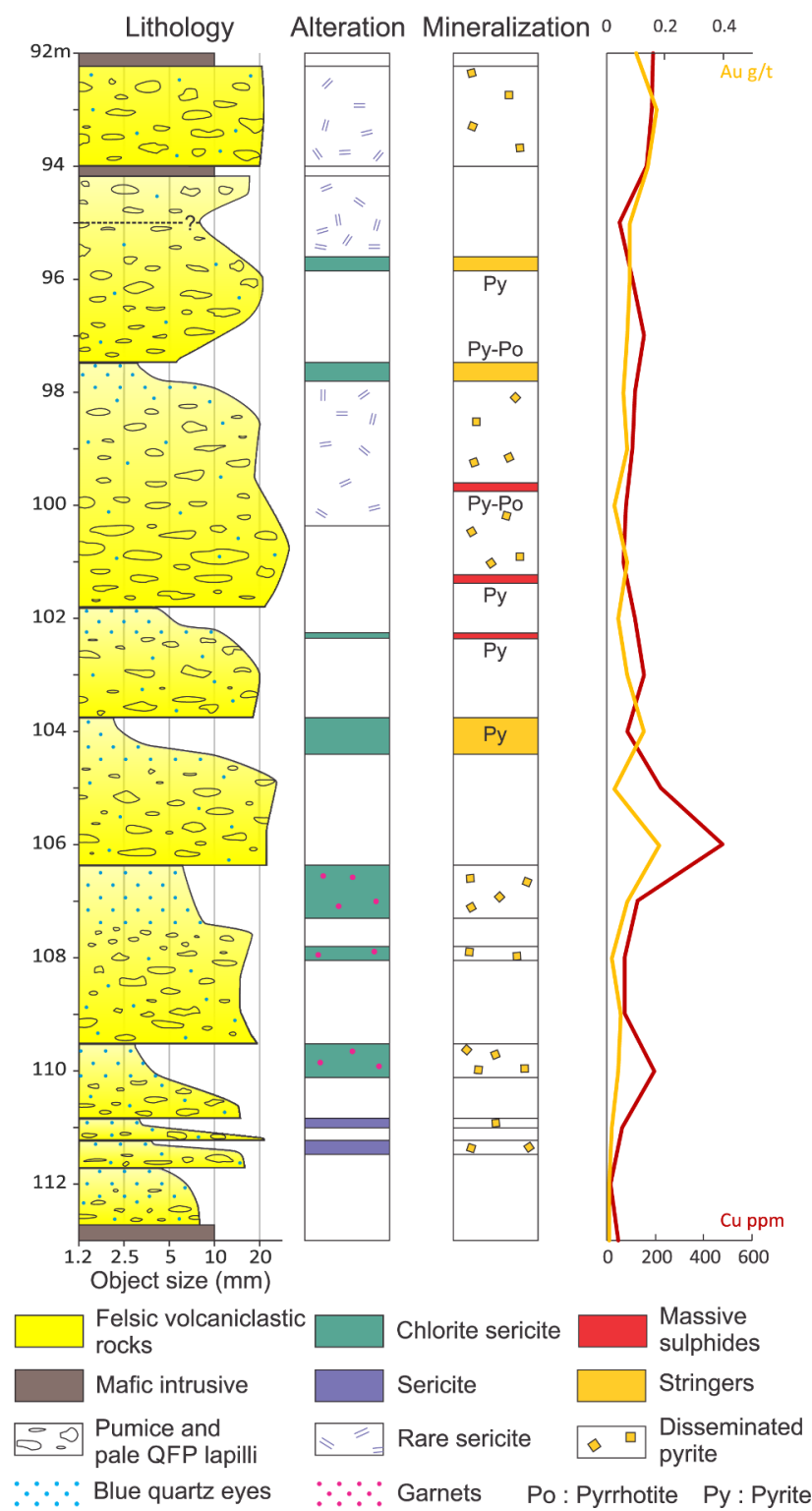

Fig. 8. Simplified stratigraphic log from a portion of drill hole MO12098, showing a typical volcaniclastic sequence of the upper occurrence of felsic lapilli tuff, in the western part of the Montagne d'Or sequence. See text for discussion.

mudstone, shale and greywacke (Fig. 5E). The bedding is usually parallel to the regional schistosity and competency contrasts between greywacke and mudstone have generated pinch-and-swell and boudinage structures (Fig. 5E). Greywackes vary in composition from grey to green amphibolites (containing amphibole, quartz and clinozoisite) to light grey-to-white cherty, quartz-rich sandstones with minor sericite and clinozoisite (Fig. 5F). Mudstones are made up of an assemblage of quartz-chlorite-sericite-clinozoisite.

The middle part of the USVR unit is characterized by mafic tuff and lavas. These rocks are strongly magnetic and are the cause of the strong magnetic signature of the Montagne d'Or deposit (Thomas, 2014). The mafic tuffs consist of thin, well-layered greenish layers. The mafic lavas are massive, fine-grained to microcrystalline, sometimes micro-gabbroic, and host rare quartz-epidote-plagioclase-chlorite amygdales. In the vicinity of the Chauve-Souris shear zone, these rocks are strongly deformed, showing a gradual development of plagioclase stretching. Deformation produced tectonic banding that can be mistaken for bedding. Several intrusions, mostly intermediate in composition, crosscut these rocks. Some of the more felsic intrusions are similar to the pale and dark QFPs of the CF unit.

The uppermost part of the USVR unit consists of tens of metresthick, folded siltstones and mudstones, locally preserving southward younging directions. It is interpreted as a turbidite sequence. These rocks are grey siltstones evolving into dark mudstones (Fig. 5D). Siltstone beds are in sharp contact between each other and vary from $10 \mathrm{~cm}$ - to $1 \mathrm{~m}$-thick. They sometimes preserve sole marks and load casts. Mudstones are graphitic and contain sericitized andalusite porphyroblasts (Fig. 5H). Hydrothermal alteration is limited to carbonateschlorite-epidote rims around quartz veins. Gold barren pyrrhotite and pyrite occur as dissemination or thin layers.

\subsubsection{Late intrusive rocks}

The stratigraphic sequence of the Montagne d'Or deposit is cut by syn-volcanic, post-volcanic, syn-tectonic and post-tectonic intrusive bodies. Felsic syn- and post-volcanic intrusions have been described in the previous sections. Younger syn- and post-tectonic intrusions are mafic to intermediate, and are classified into four types based on textures and geochemical compositions: intermediate porphyritic intrusions, intermediate intrusive rocks in the upper part of the UFZ, diabase dikes, and mafic porphyry dikes.

Intermediate porphyritic intrusions consist of $\sim 20 \%, 1-10 \mathrm{~mm}$ euhedral feldspar phenocrysts within a greyish aphanitic groundmass (Fig. 9D). Some feldspars are recrystallized into a polycrystalline assemblage of albite, quartz and epidote. Others show locally-developed stretching (Fig. 9D). These meters-thick intermediate porphyritic sills occur at two stratigraphic positions, (1) along the HWZ, where they are 2-5 m-thick, and (2) between the UFZ and LFZ zones, where they have an average thickness of 5 to $10 \mathrm{~m}$. Westward, one of these sills cuts across the LFZ zone and follows the base of the CF unit. The eastern extension of this same intrusion cuts the CMF unit and splits into a swarm of thin fingers-like dikes typical of lateral sill termination. Both porphyritic intrusions have sharp and mostly concordant to sub-concordant contacts with hosting rocks and are crosscut by younger intrusions and diabase dikes.

An intrusion of intermediate composition, previously interpreted as a tuff horizon in the UFZ (cf. marker horizon in Bout et al., 1998; Millo, 1999), forms a $20 \mathrm{~cm}$ - to $1 \mathrm{~m}$-thick sill within the Montagne d'Or sequence. This intrusion is made up of approximately $5 \%$ of millimetric euhedral, sericitized plagioclase phenocrysts (frequently stretched) and rare biotite lenses within a dark grey to greenish groundmass (Fig. 9E) containing abundant disseminated epidote. The intrusive character of that rock is attested by the presence of chilled margins, sharp contacts, smaller subsidiary sill intrusions, and crosscutting relationships with both the CF and the CMF units as well as the Montagne d'Or mineralization.

Steeply dipping diabase dikes are abundant in the Montagne d'Or deposit and cut the entire stratigraphic sequence. These dikes are strongly magnetic and show dark green, aphanitic chilled margins evolving into an equigranular microgabbroic texture in the core of the thickest dikes (Fig. 9F) which contain 1-2\% euhedral, sometimes glomeroporphyritic plagioclase. Most diabase dikes are made up of a hornblende-epidote framework with plagioclase and quartz intergrowths. These diabase intrusions form a ENE-WSW trending dike swarm, oblique to bedding and schistosity. Dikes are $10 \mathrm{~cm}$ - to $30 \mathrm{~m}$ thick and show a sigmoidal shape on the map (Fig. 3). Some of them merge together or split into several thinner dikes, defining a complex anastomosed network. Most dikes are devoid of deformation, but a weak foliation and preferred mineral orientation locally appear at their margins. In drill cores, contacts are usually sub-concordant with the schistosity and only rarely discordant (Fig. 9F). Centimetric quartzcarbonate-chlorite-epidote veins crosscut some of these dikes, and these veins locally include pyrite-chalcopyrite-pyrrhotite sulphides linked with gold anomalies in the UFZ and LFZ. 

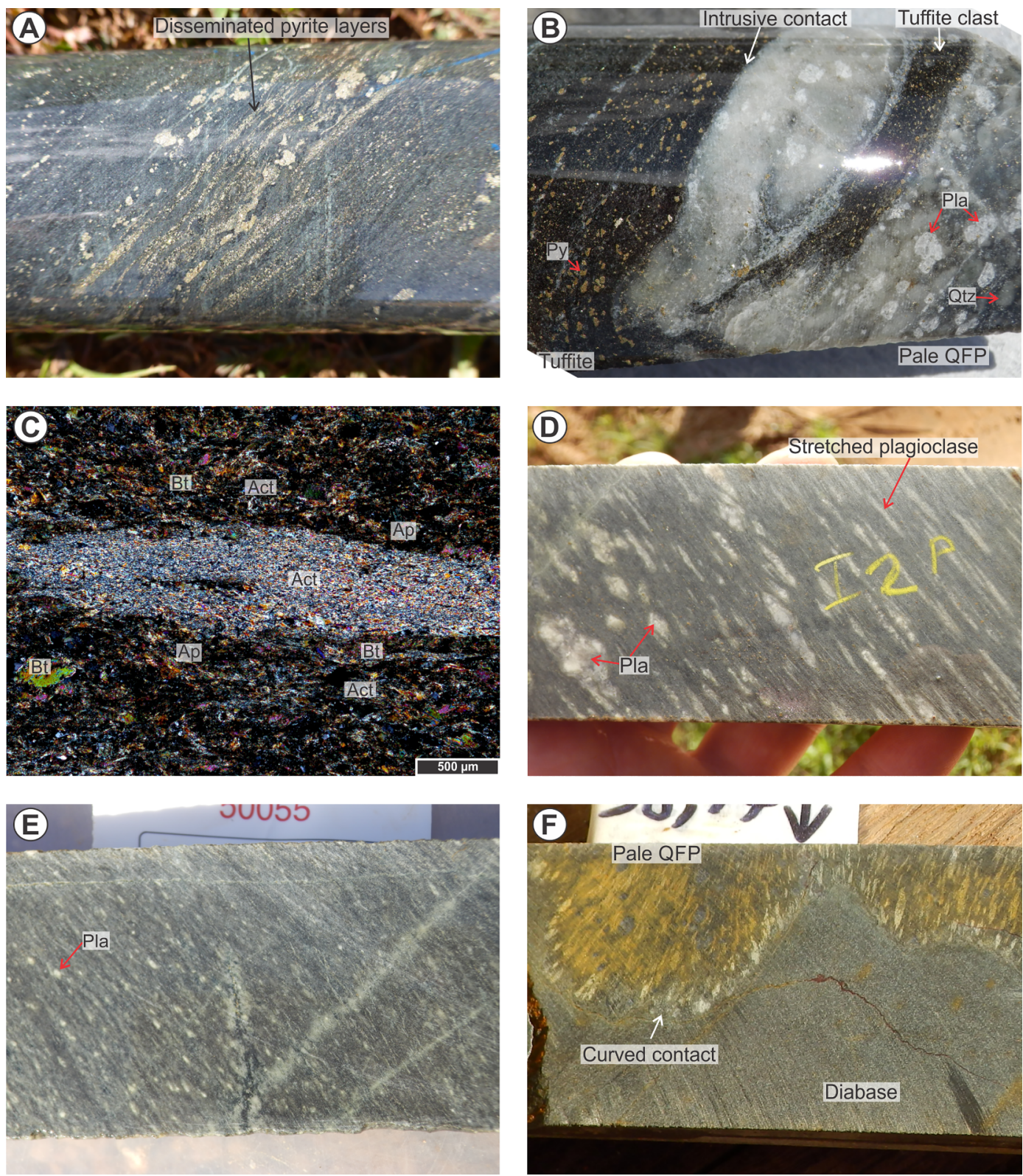

Fig. 9. Tuffite horizon of the LFZ (photos A to C) and late intrusive rocks (photos D to F). All photos of core samples show half NQ cores of $4.77 \mathrm{~cm}$ in diameter, except (F). (A) Tuffite with fine layers of disseminated pyrite (MO15263, $83.5 \mathrm{~m}$ ). (B) Intrusive contact between the pale QFP and the tuffite, showing tuffite xenoliths with pyrite dissemination (MO14154, $131.61 \mathrm{~m}$ ). (C) Photomicrograph of the tuffite showing an actinote lens, possibly a clast, within a biotite, actinote and apatite matrix. Cross-polarized light (MO14116, $114 \mathrm{~m}$ ). (D) The intermediate porphyry between the UFZ and the LFZ, showing euhedral to stretched plagioclase phenocrysts in a grey very fine-grained groundmass (MO12105, $205.5 \mathrm{~m}$ ). (E) Intermediate intrusive of the upper part of the UFZ showing small euhedral plagioclase phenocrysts (MO12098, $240 \mathrm{~m}$ ). (F) Diabase dike showing an irregular contact with the pale QFP. The diabase shows a gabbroic texture and rare isolated plagioclase phenocrysts (MO12105, $38.77 \mathrm{~m}$, HQ core $6.3 \mathrm{~cm}$ diameter).

Mafic porphyry dikes are $10 \mathrm{~cm}$ - to $1 \mathrm{~m}$-thick and occur in the eastern part of the Montagne d'Or deposit. They consist of $15-20 \%$ euhedral plagioclase phenocrysts in a dark green aphanitic and/or microcrystalline groundmass. Some clusters of plagioclase crystals show a glomeroporphyritic texture. Contacts with country rocks are sharp and clearly discordant. At least two of these dikes cut both the CF and $\mathrm{CMF}$ units. Mafic porphyry dikes are undeformed, discordant relative to the regional schistosity and are clearly post-tectonic.

\subsection{Deformation}

The Montagne d'Or stratigraphic sequence is affected by a single regional schistosity striking approximately $\mathrm{N} 85^{\circ}$ and dipping $70^{\circ}$ towards the south (Fig. 10). Structural orientations of planar fabrics and lineations are consistent throughout the deposit (Fig. 3). The schistosity is defined by platy minerals such as sericite, chlorite and biotite. Andalusite is present in some sedimentary rocks and in the hyperchlorite facies and reveals low pressure conditions $(<0.37 \mathrm{GPa})$. Chlorite dominates over biotite but mutual replacement reactions are observed. Metamorphism related to this D1 deformational event likely attains the chlorite-biotite isograd, which corresponds to the upper greenschistlower amphibolite transition. The intensity of the schistosity varies from weak to strong, more intensely foliated rocks corresponding to strongly-altered lithologies and/or mineralized facies. Competent rocks usually show well-preserved primary textures. Variations in the intensity of deformational structures are marked by heterogeneous flattening and/or stretching of geological objects such as lapilli, pumices and feldspar phenocrysts. Stretching/flattening ratios can be up to 10:1, 


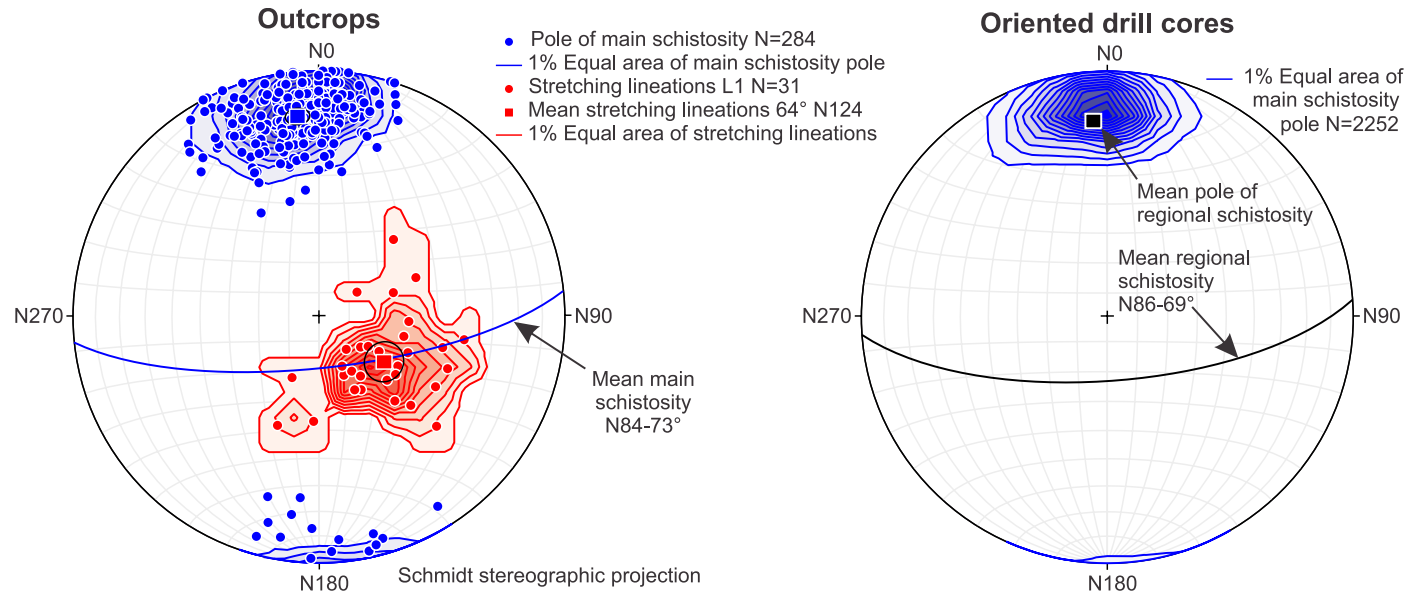

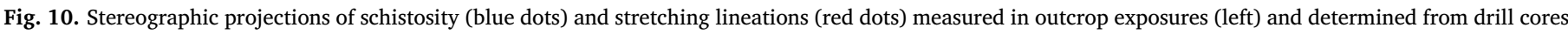
(right). See text for discussion. (For interpretation of the references to colour in this figure legend, the reader is referred to the web version of this article.)

but the average value of flattening is approximately 2:1. Mineral and stretching lineations plunge, on average, $65^{\circ} \mathrm{SE}$ (Fig. 10). Locally, shear deformation generated sigma-type porphyroclastic microstructures and related shear-sense indicators (asymmetrical pressure shadows, shear bands, mica-fish) suggest oblique, south over north, reverse-sense of faulting. Bedding is almost always transposed into the schistosity but graded-beds in volcaniclastic and sedimentary rocks consistently face south, demonstrating the homocline geometry of the Montagne d'Or sequence (Franklin et al., 2000). In drill cores, sill intrusions (i.e. intermediate porphyritic intrusions, pale and dark QFPs) are usually concordant to sub-concordant with the bedding or transposed into the schistosity. The regional schistosity is locally axial-planar to intrafolial folds in strongly altered lithologies such as, for instance, sulphide-rich horizons.

Two types of folds have been recognized. A first population of folds have S1 as an axial-planar schistosity and affect the bedding, some quartz veins and dikes. The second population consists of minor folds affecting the regional schistosity (and the bedding) and has been observed only in drill cores. The latter folds are devoid of axial-planar cleavage or schistosity and are the expression of a weak, superposed deformational event.

All the structural features of the Montagne d'Or deposit are consistent with a main deformation event resulting from north-south to NNW-SSE subhorizontal compression and subvertical extension. All the lithologies that have been dated by U-Pb geochronology (see below) are affected by these structures. However, the emplacement of diabase dikes described above shows a complex history relative to regional deformation. Franklin et al. (2000) suggested a syn-volcanic emplacement for these diabase dikes, on the basis of sub-concordant contacts with hosting rocks and the schistosity. However, diabase dikes are locally clearly discordant with the regional schistosity and at least some of them postdate the regional deformation. The core of thickest dikes showing a microgabbroic texture is usually undeformed, consistent with an emplacement postdating D1. However, relations between these diabase dikes and D2 is less clear. D2 structures clearly affect the regional schistosity by dragging diabase dike margins into them, generating weak foliation along contacts with country rocks.

There are two fault/shear zone populations affecting the Montagne d'Or sequence. The first consists of three E-W trending faults, among which the most important is the "Chauve-Souris" shear-zone. It is parallel to the regional foliation and characterized by several anastomosing high-strain corridors of ductile deformation developed in massive mafic volcanic rocks of the Upper Sedimentary and Volcanic Rocks unit. These corridors are marked by a gradual increase of feldspar stretching, producing tectonically laminated rocks interpreted as Ltectonites (Sullivan, 2013). Hubé (1997) proposed a sinistral sense-of- shear for the Chauve-Souris shear zone. Our microstructural and structural analysis indicates a reverse-sense of movement (south-overnorth) with a dextral component. In the absence of clear stratigraphic and metamorphic grade offsets along that fault, the amount of displacement is considered as moderate. There is another E-W trending fault mapped along graphitic layers located in the top of the Lower unit. This fault is defined by a 2-3 m-thick tectonic breccia, indicating that it formed under brittle conditions. The location of a third E-W trending structure at the contact between the foliated tonalite and the Lower unit is based on geophysics.

The second fault population is younger and trends N-S, perpendicular to the previous one. Some of these faults cut all rock types of the Montagne d'Or area including diabase dikes and most of them are minor structures. The steeply-dipping Infirme fault is the most significant of these faults, it is marked by fault gouge and shows an apparent sinistral sense of movement at map scale (Fig. 3).

\section{U-Pb zircon geochronology}

In order to constrain the age of the Montagne d'Or deposit and its host rocks, four samples of volcanic and intrusive rocks were selected for U-Pb geochronology on zircons. The selected rock samples are from drill cores, and comprise the felsic tuff unit, the pale QFP, the dark QFP sill of the LFZ and the intermediate feldspar porphyry. To preserve the integrity of the drill cores, only a quarter of the core was taken. Altered rocks, mineralized intervals, veins and dikes were removed from samples. For both the felsic tuff unit and the dark QFP sill, two samples were used in order to enhance the number of separated zircon grains. The felsic tuff unit duplicate comes from the same drill core but in deeper parts of it. The two samples of dark QFP sill are from the same intrusion but two different drill cores.

\subsection{Analytical methods}

U-Pb-Th laser ablation-inductively coupled plasma-mass spectrometry (LA-ICP-MS) was performed at the Geotop laboratory of Université du Québec à Montréal (See Table A1 for the analytical methodology and Supplementary Appendix 1 for results). Zircons were hand-picked and classified according to the criteria set up in literature (Pupin, 1980; Corfu et al., 2003). For each sample, 50 to 90 selected zircon grains were mounted and then examined by scanning electron microscopy (SEM) in back-scattered electron (BSE) mode as well as by cathodoluminescence in order to determine the internal structure of rims, cores and cracks, and to select the best spots for analysis (Fig. 11). All age uncertainties are presented at the $2 \sigma$ level. 


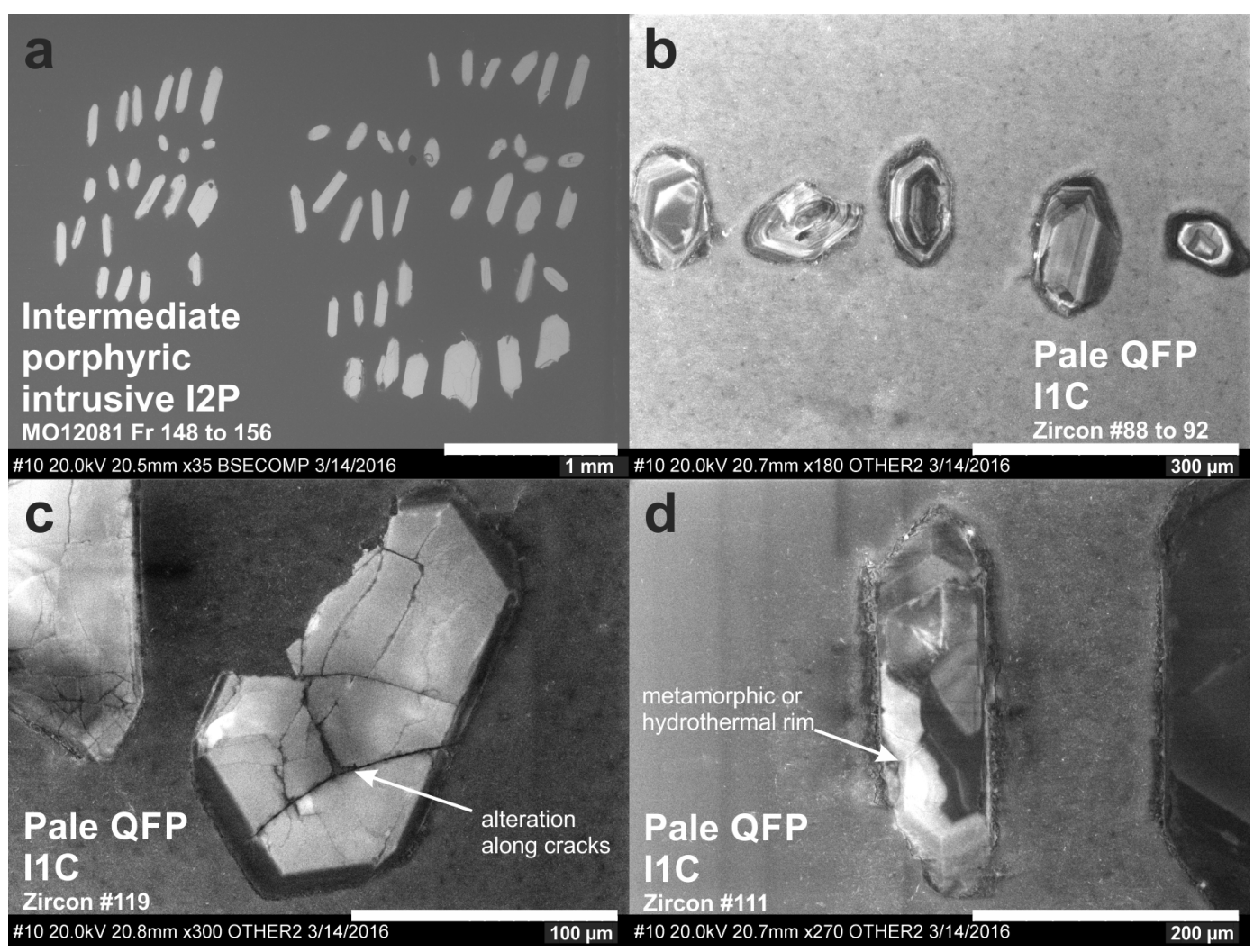

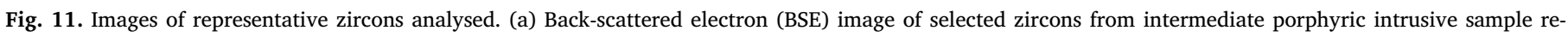

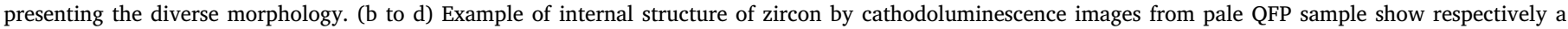
magmatic growth zoning, a diffuse alteration along cracks and an interpreted metamorphic or hydrothermal rim in the whitish part of zircon.

\subsection{Results}

The size of analyzed zircon grains varies between 50 and $200 \mu \mathrm{m}$, sometimes $400 \mu \mathrm{m}$ (Fig. 11). These zircons are colorless, or slightly yellowish to pinkish. Most zircon grains are prismatic, but stubby, stalky, needle-like shapes are also present (Fig. 11a). In some samples, a few zircons display complex twinning. All grains reveal classic magmatic zoning with a noticeable absence of inherited cores (Fig. 11b). Some of them show thin hydrothermal and/or metamorphic rims (Fig. 11c, d). The same zircon populations are found in the various rock facies. Most zircons cluster on the Concordia curve, but some grains display evidence of $\mathrm{Pb}$ loss, generating discordant points (Fig. 12). Only two analyses from the felsic tuff and five analyses from the dark QFP were outliers and have been rejected for age calculations. These rejected analyses reveal an over-saturated spectrum or contain common $\mathrm{Pb}$. The lower intercept between Discordia and Concordia curves from the analyzed samples yields scattered ages with no geological significance, suggesting recent $\mathrm{Pb}$ loss. Therefore, we fixed $\mathrm{Pb}$ loss to zero in order to produce concordant ages.

Felsic tuff: The felsic tuff sample comes from drill hole MO14171 from 56.2 to $60.3 \mathrm{~m}$ and 82.2 to $84.2 \mathrm{~m}$ on section 173050 . This sample is located 20 to $50 \mathrm{~m}$ above the UFZ. The analysed zircons yield a Concordia age of $2152.4 \pm 4.1 \mathrm{Ma}$ (Fig. 12A), that is interpreted as the age of crystallization of zircons and deposition of this felsic tuff facies.

Pale QFP: The analysed sample of pale QFP is from the same drill core as the felsic tuff, from a depth of 246.3 to $254 \mathrm{~m}$. There, this pale QFP is located between the UFZ and LFZ mineralization zones. The analysed zircon grains yielded a Concordia U-Pb age of $2146.5 \pm 4.7$ Ma (Fig. 12B) which we interpret as the age of crystallization.

Dark QFP sill: This facies was sampled in drill cores on section 172550: from 68.6 to $76.8 \mathrm{~m}$ in hole MO14188 and from 163.2 to
$167 \mathrm{~m}$ in hole MO14206. Along these two drill holes, the dark QFP sill lies just a few metres above the LFZ. The analysed zircons yielded a Concordia U-Pb age of $2129.9 \pm 5.3 \mathrm{Ma}$ (Fig. 12C) interpreted as a crystallization age.

Intermediate feldspar porphyry: This sample is from drill core MO12081, from 148 to $156 \mathrm{~m}$ on section 174275 . There, the intermediate feldspar porphyry cuts the CMF unit just below the UFZ. However, in other sections, this porphyry crosscuts the pale QFP, the felsic tuff, the dark QFP and the LFZ mineralization. The analyzed zircons yielded a Concordia age of $2117.6 \pm 5.1 \mathrm{Ma}$ (Fig. 12D) which we interpret as the age of crystallization of the porphyry.

\subsection{Synthesis and interpretation of geochronology data}

The absence of inherited zircons suggests that the Montagne d'Or magmatic sequence did not form over an older continental basement. Concordant $\mathrm{U}-\mathrm{Pb}$ ages are similar (within errors) in both the felsic tuff (i.e. $2152.4 \pm 4.1 \mathrm{Ma}$ ) and the pale QFP (i.e. $2146.5 \pm 4.7 \mathrm{Ma}$ ), suggesting a possible synvolcanic origin for the latter. Such ages are consistent with constraints presented by Delor et al. (2003b) who provided a Pb-evaporation zircon age of $2152 \pm 8 \mathrm{Ma}$ for a rhyolite from the Infirme creek (Fig. 3). The two other dated samples, the dark QFP and the intermediate feldspar porphyry, are significantly younger, and are therefore post-volcanic. The dark QFP, which crosscuts the felsic tuff, the pale QFP and the CMF unit, yields a crystallization age of $2129.9 \pm 5.3 \mathrm{Ma}$. The intermediate feldspar porphyry, which crosscuts the entire volcanic sequence of the Montagne d'Or deposit, yields a younger age of crystallization at $2117.6 \pm 5.1 \mathrm{Ma}$. The U-Pb geochronology results are consistent with the observed crosscutting relationships.

Although there is a significant time gap between the felsic tuff and pale QFP, on one hand, and the dark QFP, on the other hand, these 


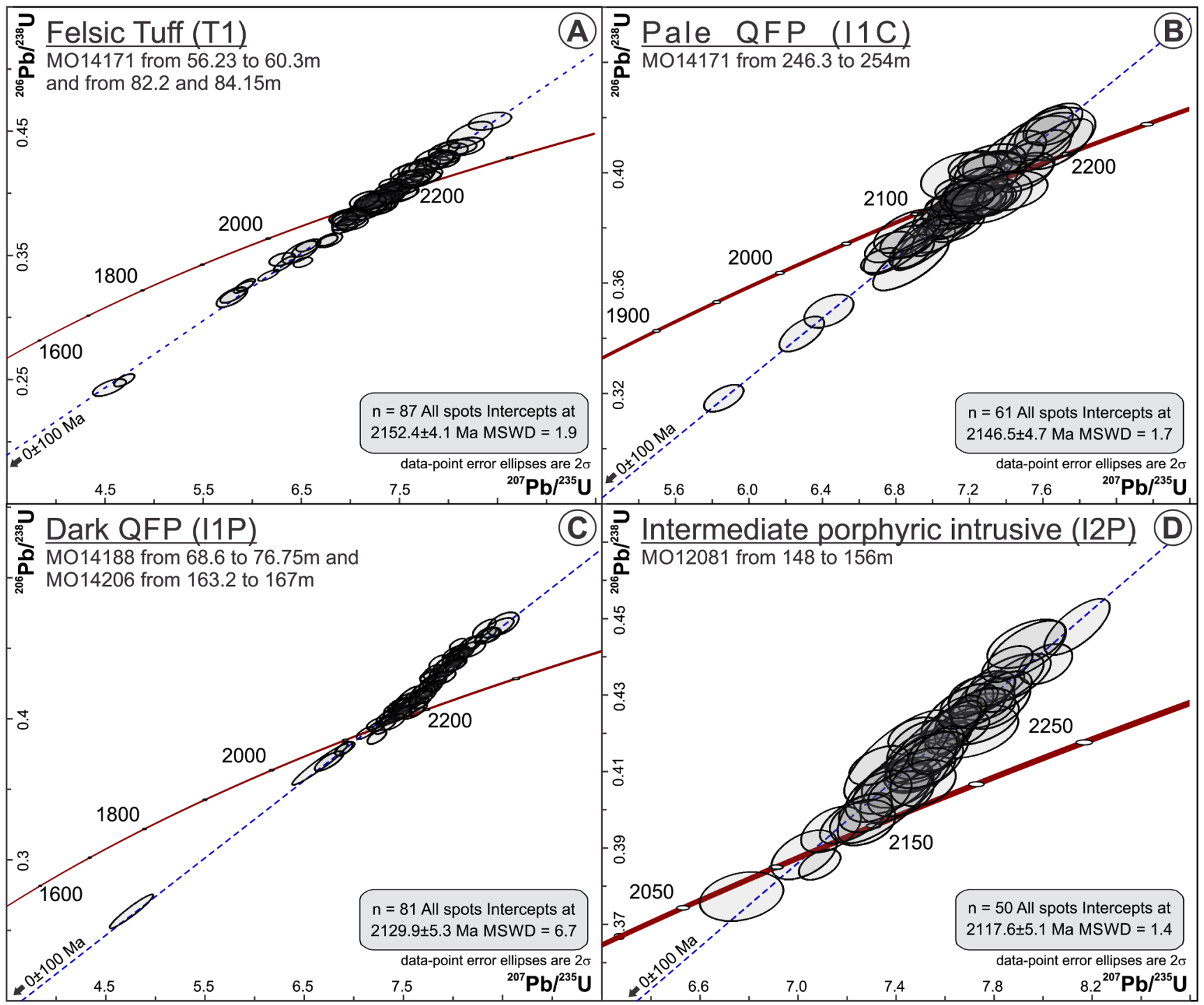

Fig. 12. U-Pb Concordia diagrams for zircons from intrusive and extrusive rocks of the Montagne d'Or sequence. (A) The felsic tuff yields $2152.4 \pm 4.1$ Ma. (B) The pale QFP yields $2146.5 \pm 4.7 \mathrm{Ma}$. (C) Dark QFP of the LFZ yields an age of $2129.9 \pm 5.3 \mathrm{Ma}$. (D) The intermediate porphyric intrusion, which cuts the LFZ mineralization and CMF-CF units, yields $2117.6 \pm 5.1 \mathrm{Ma}$.

three units are thought to be genetically related (i.e. in terms of source, crustal contamination and magmatic evolution; Guiraud et al., 2015). Also, the dark QFP intrusions are locally affected by a chlorite-sericite hydrothermal alteration and are host to low-grade mineralization. Our observations show that the Montagne d'Or mineralization occurred by subsea-floor replacement processes within felsic tuffs facies (e.g. Fig. 7C), as suggested by Franklin et al. (2000). This implies that the main hydrothermal system related to the gold mineralization has to be younger than the age of the tuffs. This system may have been still active during (or slightly after) the emplacement of dark QFPs at $2129.9 \pm 5.3 \mathrm{Ma}$, or more likely, hydrothermal activity stopped but was briefly reactivated at that time. The Montagne d'Or volcanic and intrusive felsic rocks thus represents an exceptionally long-lived magmatic-system, which was active for a time-period as long as 16 m.y. However, as suggested by Galley (2003), Gibson et al. (2007), and Piercey (2011), one to several millions years period of activity represents a duration that can be reasonably expected in volcanic systems, as preserved, for instance, in the Wolverine deposit (Yukon, Canada), where a time gap of $5 \mathrm{~m}$.y. between the emplacement of earliest intrusions and syn-VMS intrusions has been documented (Piercey et al., 2008). Another example is the Kidd Creek VMS deposit (Abitibi, Canada) for which Bleeker and Parrish (1996) argued for a period of 2.8 to
6.5 m.y. of ore formation by dating the footwall and hanging-wall felsic rocks.

The intermediate feldspar porphyry, which yielded the youngest U$\mathrm{Pb}$ zircon age, is devoid of sulphide mineralization and alteration, and its geochemical signature indicates that it belongs to a different magmatic pulse. It crosscuts the LFZ mineralization and alteration halos, hence constraining a minimum age for the Montagne d'Or mineralization at $2117.6 \pm 5.1 \mathrm{Ma}$.

\section{Volcanic environment and evolution of the Montagne d'Or deposit}

In this section, we propose an interpretation of the different lithological facies of the Montagne d'Or sequence in terms of paleo-environment and volcanic processes.

\subsection{Depth of the marine basin}

The oceanic depth of formation is an important parameter in mineralized submarine volcanic systems, in terms of metal deposition processes and distribution, seawater and hydrothermal fluid interactions, as well as boiling and fluid separation processes (Gibson et al., 
1999; Franklin et al., 2005). Overall, the characteristics of the volcanic, volcaniclastic and sedimentary rocks of the Montagne d'Or sequence suggest a water depth ranging between 500 and $1000 \mathrm{~m}$, based on the following points. (1) Volcaniclastic and sedimentary rocks of the Montagne d'Or sequence are devoid of dynamic sedimentary structures (e.g., cross-laminations, wave-ripples...) which is a strong indication of a water depth below the wave base (i.e. > $200 \mathrm{~m}$; McPhie et al., 1993; Allen et al., 1996b; Gibson et al., 1999). (2) Sedimentary rocks are dominated by immature, very fine-grained and thin layers of greywacke and Fe-rich mudstone, interpreted as a turbidite sequence for the USVR, suggesting a relatively deep marine environment (Walker, 1967; Kneller, 1995). (3) The sedimentary rocks contain more mafic than felsic detritus, whereas rare lithic clasts found in these rocks consist of angular fragments of mudstone, pale QFP and chert, attesting for local sources with limited transport in an off-shore environment. We think that the sedimentary rocks were produced by reworking of volcanic and intrusive rocks due to volcanic eruptions, and to mass-flows and/or turbidite deposition rather than by erosion of an emerged landmass. (4) The low vesicularity and the lack of evidence for explosive activity of the tholeiitic mafic lavas implies emplacement depths of at least $200 \mathrm{~m}$ (Kokelaar, 1986). (5) Felsic volcaniclastic rocks containing pale QFP and pumice fragments formed directly or indirectly by explosive volcanic events. In modern settings, such rock facies occur predominantly at water depths shallower than $1000 \mathrm{~m}$, more frequently above $500 \mathrm{~m}$ (Kokelaar, 1986; Klug and Cashman, 1996; Gibson et al., 1999), although explosive felsic volcanism can occur in deeper water ( $>1000 \mathrm{~m}$ ), such as documented in the Kermadec arc (see Wright and Gamble, 1999; de Ronde et al., 2005; Carey et al., 2018). (6) At water depths deeper than $500 \mathrm{~m}$, the confining pressure is high enough to promote sill-like emplacement of felsic magmas (Kokelaar, 1986; Walker, 1989; McPhie et al., 1993), which is consistent with the abundance of intrusive rocks occurring as sills in the Montagne d'Or sequence. (7) On the basis of metal distribution, Franklin et al. (2000) proposed that the Montagne d'Or mineralization formed by replacement processes below the seafloor, at a water depth between 500 and $1000 \mathrm{~m}$. Our results are consistent with this depth estimation.

\subsection{Synchronicity of mafic and felsic magmatism}

The Montagne d'Or volcanic sequence is bimodal but mafic volcanic rocks and related mafic sedimentary rocks predominate over felsic rocks overall. Geochemical analyses reveal that these tholeiitic mafic rocks and calc-alkaline felsic rocks are genetically unrelated (Franklin et al., 2000), as also suggested by the lack of volcanic rocks with transitional magmatic affinities.

Yet the broad synchronicity of felsic and mafic magmatism is indicated by several lines of evidence. Mafic volcaniclastic rocks of the Lower unit contain felsic clasts, whereas the lowermost felsic lapilli tuffs of the CF unit contain mafic clasts. The occurrence of pale QFP clasts moreover suggests that the pale QFP intruded before or during deposition of the Lower unit. To the opposite, overlying lapilli tuffs of the $\mathrm{CF}$ unit containing clasts of mafic rocks indicate that some mafic eruptive facies were formed before the CF unit. Rare pale QFP clasts are also found in mafic rocks of the CMF unit. Finally, probably the best evidence for mafic/felsic magmatic synchronicity is shown by the emplacement of a mafic tuff horizon (containing felsic pumice and pale QFP lapilli) in the felsic volcaniclastic sequence occurring in the western part of the CF unit, above the Hanging-Wall Zone (Fig. 6C).

\subsection{Eruption processes and volcanic vents}

Mafic and felsic vents. All the above observations indicate the synchronicity of mafic and felsic magmatism during a bimodal volcanic regime. This can be reasonably attributed to the activity of at least two volcanic centers (one mafic, one felsic). The relative positions of these volcanic centers can be estimated on the basis of lateral lithological variations and distribution. The mafic volcanic rocks of the CMF unit, for instance, preserve abundant pillowed and massive basaltic flows in the eastern part of the Montagne d'Or sequence, whereas it is reduced to a single mafic tuff horizon in the western part of the sequence, suggesting the location of a mafic volcanic center in the east (Ross, 2014). Similarly, the geometry and lateral distribution of felsic rocks can be used to infer the relative position of felsic vent center(s), considering that (1) felsic tuffs form thin beds of limited lateral extent in the CMF unit, (2) the lapilli tuff-bearing sequence at the top of the CF unit progressively disappears eastward, and (3) the proportion of pale QFP gradually increases westward. All of this suggests that a felsic eruptive and intrusive center occupies the western part of the Montagne d'Or deposit or is located further west.

Volcanic hiatus in the bimodal formation. In the Lower unit and the USVR, volcanic rocks are interbedded with sedimentary rocks, indicating several pauses in the volcanic activity. In contrast, much of the bimodal magmatism may have been formed relatively rapidly, as suggested by the absence of interbedded sediments, the lack of thin and well-developed bedding and lamination, and the juvenile-rich composition of felsic and lapilli tuffs in the CF unit (McPhie et al., 1993; Allen et al., 1996a). However, the presence of a tuffite in the LFZ indicates a volcanic hiatus within the $\mathrm{CF}$ sequence. In order to account for the high $\mathrm{Ni}$ contents of that tuffite, Franklin et al. (2000) suggested that the sulphides were organically-generated in a sedimentary environment, an interpretation that is consistent with our observations. The internal geometry of mafic/felsic rocks of the CMF unit and the deposition of tuffite above them suggest that the bimodal magmatic cycle started with a felsic pulse from the west, followed by eastward-sourced basaltic flows and deposition of the tuffite (Fig. 13) after a pause of volcanism. Volcanic activity repeated afterward with the same type of volcanic succession, i.e. starting with a felsic pulse.

Origin of the felsic volcaniclastic rocks. In the uppermost part of the felsic sequence, lapilli tuff and tuff beds are thick (i.e. $20-100 \mathrm{~cm}$ or more; Fig. 8), rich in juvenile fragments, non-welded, and contain subangular clasts. They are interpreted as deposited by eruption-fed subaqueous density currents (White, 2000) rather than subaqueous pyroclastic flows related to a caldera-collapse. The lapilli tuff at the base of $\mathrm{CF}$ unit is well bedded but its origin remains poorly constrained. The rest of the felsic volcaniclastic rocks appear poorly stratified; they are often more hydrothermally-altered, mineralized and tectonically-deformed, which hides their primary structures and textures and, for these reasons, they do not have a well-established origin at this stage.

Origin of the pale QFP. The pale QFP is everywhere intrusive into the felsic tuff and lapilli tuff. In the eastern part of the CF unit, this pale QFP consists of transposed thin dikes and sills (i.e. 1-2 m). The pale QFP thickens westward, evolving into a ca. 100-meter-thick intrusion. Intrusive contacts are rarely exposed but are usually sharp, with thin chilled margins. The exact nature of this QFP is difficult to establish due to the absence of well-exposed outcrops. In drill core, the pale QFP lacks perlitic textures, flow banding and spherulites commonly found in subaqueous lava domes or cryptodomes (e.g. McPhie et al., 1993). Neither is it associated with clear hyaloclastite. Moreover, if the jigsaw breccia (Fig. 6F) observed near the contact of the CF unit and Lower unit is hydrothermally-derived, then there is no peperite at the contact between these pale QFP intrusions and their host rocks. All of this suggests an intrusive relationship with the felsic volcaniclastic rocks. The lack of peperite moreover suggests that the country rocks may already have been partly consolidated at the time of QFP intrusions.

\subsection{Evolution of the Montagne d'Or volcanic sequence}

The proposed moderate water depth, combined with the coexistence of mafic tholeiitic and calc-alkaline volcanism and related sedimentary influx, support a back-arc environment. Our study of the different lithological facies and the inferred environments of deposition of the Montagne d'Or sequence allows us to propose a synthetic model 


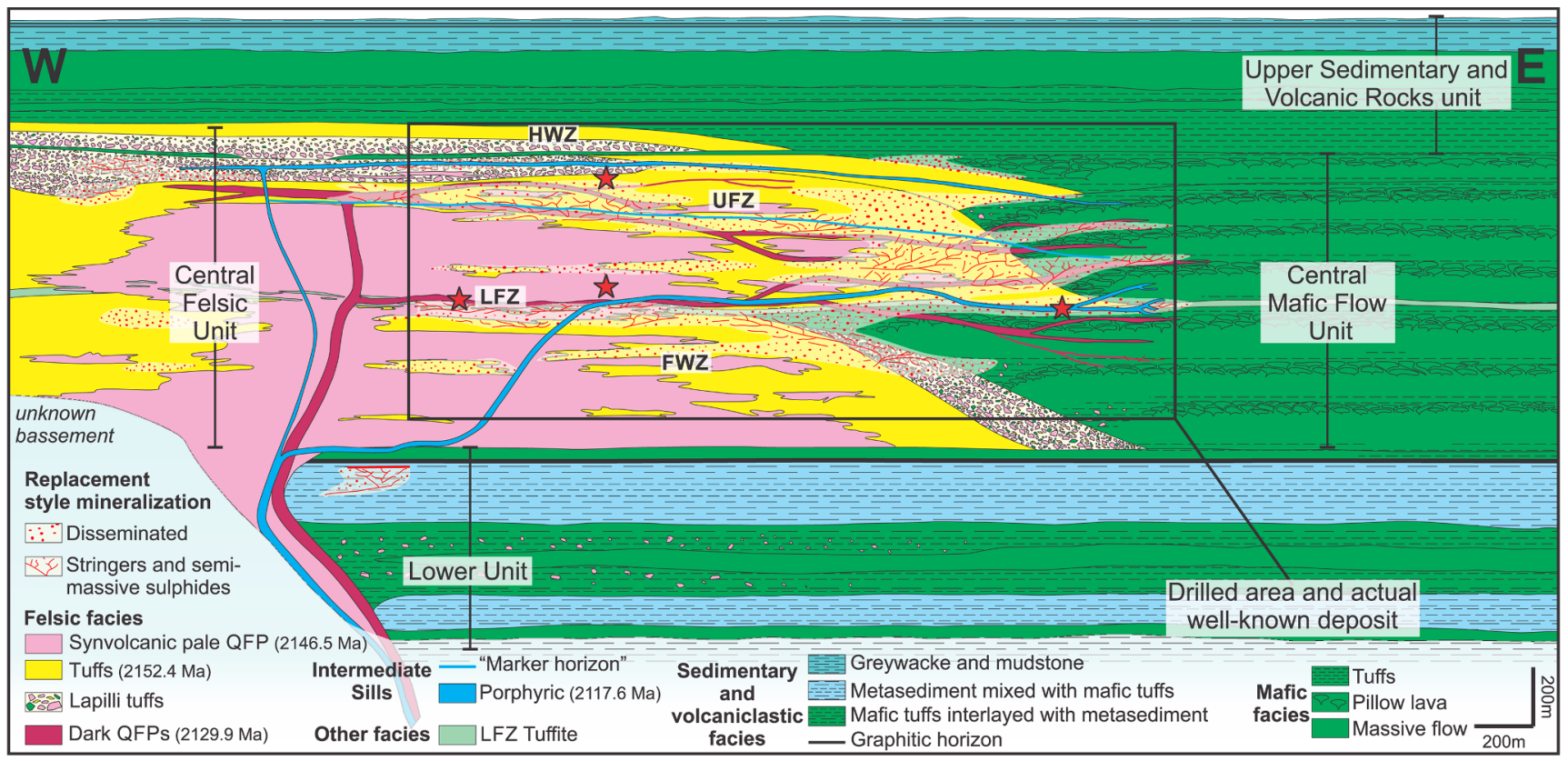

Fig. 13. Schematic stratigraphic reconstruction of the geological environment of the Montagne d'Or VMS deposit. Red stars are the approximate location of dated samples. See text for discussion.

\section{(Figs. 13 and 14) for its stratigraphic evolution.}

The first eruptive cycle formed the Lower unit, which comprises a variety of different lithological facies such as tholeiitic mafic massive flows and tuffs interlayered with fine-grained and finely-bedded volcanic mudstones and greywackes (Fig. 14a). Mixed felsic/mafic intercalations occur, showing that felsic volcanism was already active during the formation of the Lower unit. The uppermost part of the sequence is marked by thin layers of graphitic mudstone, indicating a pause of volcanism.

The bimodal sequence of the CMF and CF units, was probably generated by two volcanic centers. The mafic volcanic vent was located to the east, perhaps at a distance of 1 to $10 \mathrm{~km}$ from the core of the Montagne d'Or deposit, whereas the felsic volcanic center was located perhaps a few $\mathrm{km}$ west of the deposit (Fig. 13). The first major cycle of felsic volcanism created a significant amount of volcaniclastic material. Early phases of the pale QFP may have intruded the volcaniclastic pile at this stage (Fig. 14b), although it is also possible that it was emplaced somewhat later, given the absence of peperite (see above). Eastward, correlative distal facies are preserved as a sequence of felsic lapilli tuffs enriched in mafic lithic clasts originating from the underlying mafic rocks of the Lower unit. Several mafic volcanic flows, and the uppermost mafic tuffite, then formed and draped over the felsic rocks towards the end of this eruptive cycle (Fig. 14c).

During the second eruptive cycle of bimodal magmatism, additional felsic volcaniclastic units were deposited (Fig. 14d). As for the earlier cycle, a pause of felsic volcanism was followed by the emplacement of mafic tuffs (Fig. 14e). The bulk of the pale QFP likely intruded the volcaniclastic sequence at this stage. The VMS mineralization was emplaced through subsea-floor replacement (Franklin et al., 2000), presumably at no more than a few hundred metres below the seafloor (Doyle and Allen, 2003). The pale QFP may has been the shallow intrusive expression of a deeper magmatic body which would have been the source of heat, fluids and perhaps gold of the hydrothermal system that produced the Montagne d'Or deposit (e.g., Huston et al., 2011; Mercier-Langevin et al., 2011).

The uppermost part of the Montagne d'Or sequence, consisting of the 1-2 km-thick USVR was then deposited (Fig. 14f). Mafic tuffs evolve upwards into greywackes and interlayered tholeiitic mafic flows, both overlain by turbiditic greywackes and mudstones with a marker horizon of graphitic mudstone at the top.

Dark QFPs, probably sills, intruded the whole sequence as a postvolcanic phase of felsic magmatism (Fig. 14g). A very minor amount of mineralization may have been emplaced around this time. Afterwards, two porphyritic intrusions of intermediate composition crosscut the mineralization and its alteration halos (Fig. 14h).

Finally, the Montagne d'Or sequence and mineralization have been transposed, stretched and metamorphosed during a regional D1 event (not shown on Fig. 13). A weakly expressed secondary deformation event affects the regional schistosity as manifested by minor folds and possible reworked structures but without axial-planar cleavage or schistosity. Dikes of diabase cut all lithologies and post-date the S1 schistosity. However, the emplacement of diabase seems complex and less clear with the D2 event. These diabase dikes could be ante- to syntectonic relative to this event and thus belong to a Rhyacian population of diabase dikes.

\section{The significance of the Montagne d'Or volcanic sequence within the Guiana Shield}

There are several features suggesting that the Montagne d'Or volcanic sequence formed in a back-arc environment: (1) the predominance of fine-grained siliciclastic rocks indicating a relatively deep sedimentary basin, far from a continental margin; (2) the synchronicity of tholeiitic and calc-alkaline volcanism; (3) the moderately fractionated REE spectrum of felsic rocks indicating a weak amount, if any, of crustal contamination (Franklin et al., 2000; Guiraud et al., 2015); (4) the lack of geochemical evidence for crustal contamination in the mafic rocks; and (5) the absence of inherited zircons in the dated samples.

In French Guiana, volcanic sequences associated with the Paramaca Greenstone Belt have ages similar to that of the Montagne d'Or volcanic sequence and are also prospective for VMS exploration. The Montagne d'Or sequence is also similar to the St-Élie volcanic rocks, which are exposed west of Petit-Saut lake (Fig. 2) and form a bimodal volcanic suite comprising tholeiitic basalts and calc-alkaline andesites and rhyolites, intruded by the Devis granodiorite (Lafrance et al., 1999). The rhyolite and granodiorite of St-Élie yielded discordant U-Pb zircon ages of $2148+4 /-3 \mathrm{Ma}$ and $2146 \pm 2 \mathrm{Ma}$, respectively (Lafrance et al., 1999), which is in the same age range as our U-Pb results. 


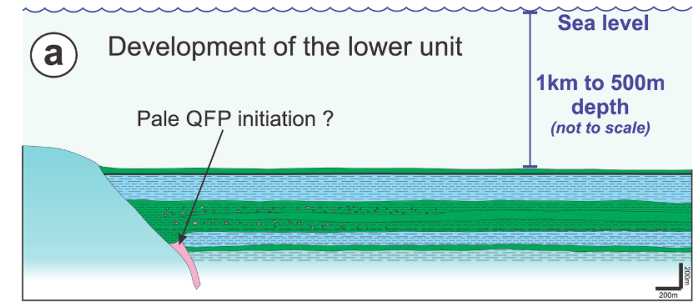

(C) First mafic flows volcanism and LFZ tuffite deposition

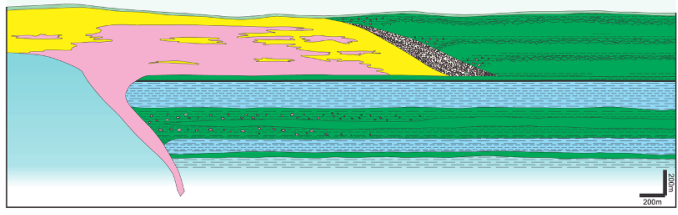

(e) Coeval felsic/mafic magmatism
and replacement mineralization $\begin{gathered}1 \mathrm{~km} \text { to } 500 \mathrm{~m} \\ \text { depth }\end{gathered}$

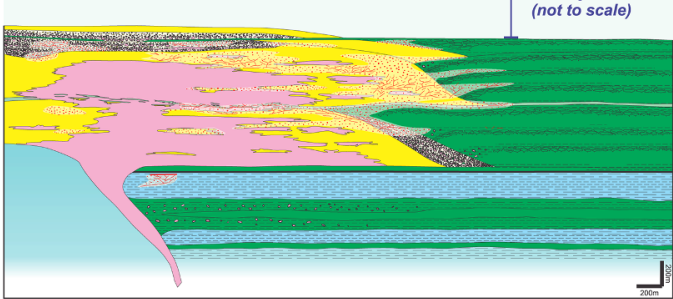

(g) Dark QFP sills and minor mineralization event $2129.9 \mathrm{Ma}$

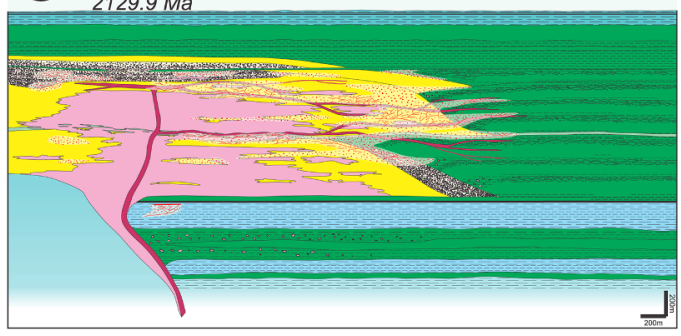

(b) First felsic event $2152.4 \mathrm{Ma}$

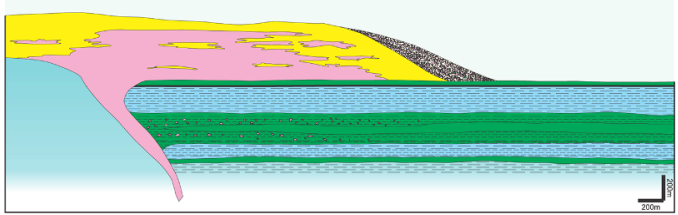

(d) Second felsic pulse and reworking

of the pale QFP intrusions $2146.5 \mathrm{Ma}$
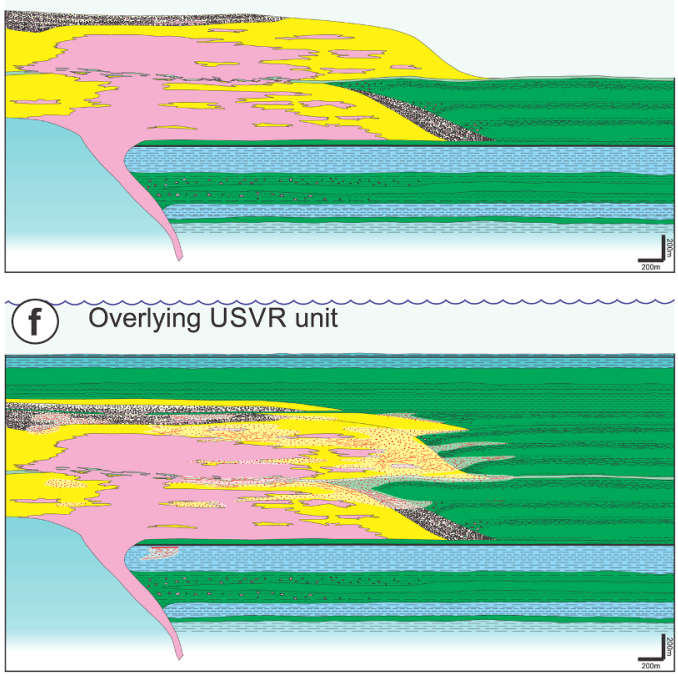

(h) Late-stage feldspar porphyry event $2117.6 \mathrm{Ma}$

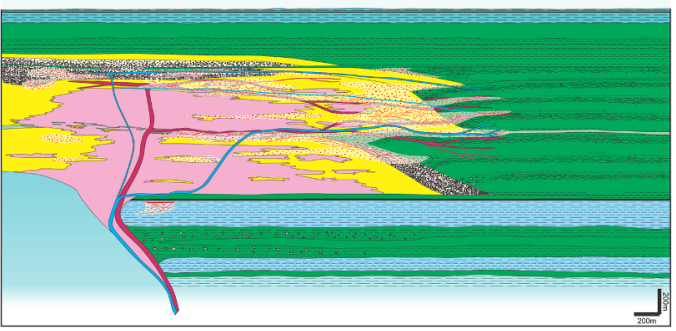

Fig. 14. Stratigraphic evolution of the Montagne d'Or volcanic and sedimentary sequences. Water depth is not to scale. See text for details.

Table 1 presents a compilation of geological and mineral characteristics of Rhyacian, volcanic-related mineral deposits and/or prospects of the northern Guiana Shield, that may potentially be VMS settings comparable to the Montagne d'Or sequence. Their locations are shown on Fig. 1. However, typical VMS settings are rare in the Guiana Shield, contrary to classic VMS districts that usually comprise tens of mineralized systems (Franklin et al., 2005). This rarity possibly reflects the lower exploration activity in the region. The few occurrences that are listed in Table 1 are, moreover, also poorly documented, especially Groete Creek and Aremu in Guyana.

Groete Creek shares several similarities with the Montagne d'Or deposit. Both are hosted by a bimodal volcanic sequence attributed to an oceanic back-arc system; the geodynamic interpretation of Groete Creek being based on the geochemistry of volcanic rocks of the BaramaMazaruni Supergroup (Voicu et al., 1997). The Groete Creek sequence shows a volcanic assemblage very similar to Montagne d'Or, with interbedded felsic and mafic volcaniclastic rocks and sedimentary rocks. As for Montagne d'Or, Groete Creek mineralization consists of stratiform disseminations, stringers and semi-massive sulphides along several stratigraphic horizons.

The Dorlin deposit in French Guiana (Table 1) has been described as a stratabound, exhalative gold-bearing tourmalinite (Milési et al., 1988,
2003; Lerouge et al., 1999). Dorlin comprises subvolcanic intrusions, as well as volcaniclastic rocks indicating explosive volcanism and finegrained sedimentary rocks attributed to submarine environment (Milési et al., 1988; Lerouge et al., 1999). The Dorlin volcanic sequence is cut by intrusive rocks that yielded $\mathrm{Pb} / \mathrm{Pb}$ zircon ages of $2127 \pm 7$ and $2123 \pm 4$ Ma (Milési et al., 1995), indicating that these volcanic rocks and related mineralization are older than these intrusions, which is consistent with the inferred timing of the Montagne d'Or deposit. In contrast to the bimodal Montagne d'Or and Groete Creek volcanic sequences, the Dorlin magmatic system represents a single suite of intermediate to felsic volcanic rocks, and both its timing and geodynamic setting remain unknown.

In Brazil, the Serra do Ipitinga deposit (Dardenne and Schobbenhaus, 2003) has an inferred back-arc tectonic setting and contains interlayered sedimentary rocks in the volcanic sequence, as for other volcanogenic settings of the Guiana Shield. However, it differs from the Montagne d'Or in several ways: (1) the footwall sequence comprises mafic and ultramafic rocks, (2) lenses of massive sulphides are present, and (3) it is spatially associated with an Algoma-type iron formation (Bekker et al., 2010). Serro do Ipitinga belongs to the maficsiliciclastic VMS type deposits described by Franklin et al. (2005). In contrast with Montagne d'Or, the abundance of clastic sedimentary 


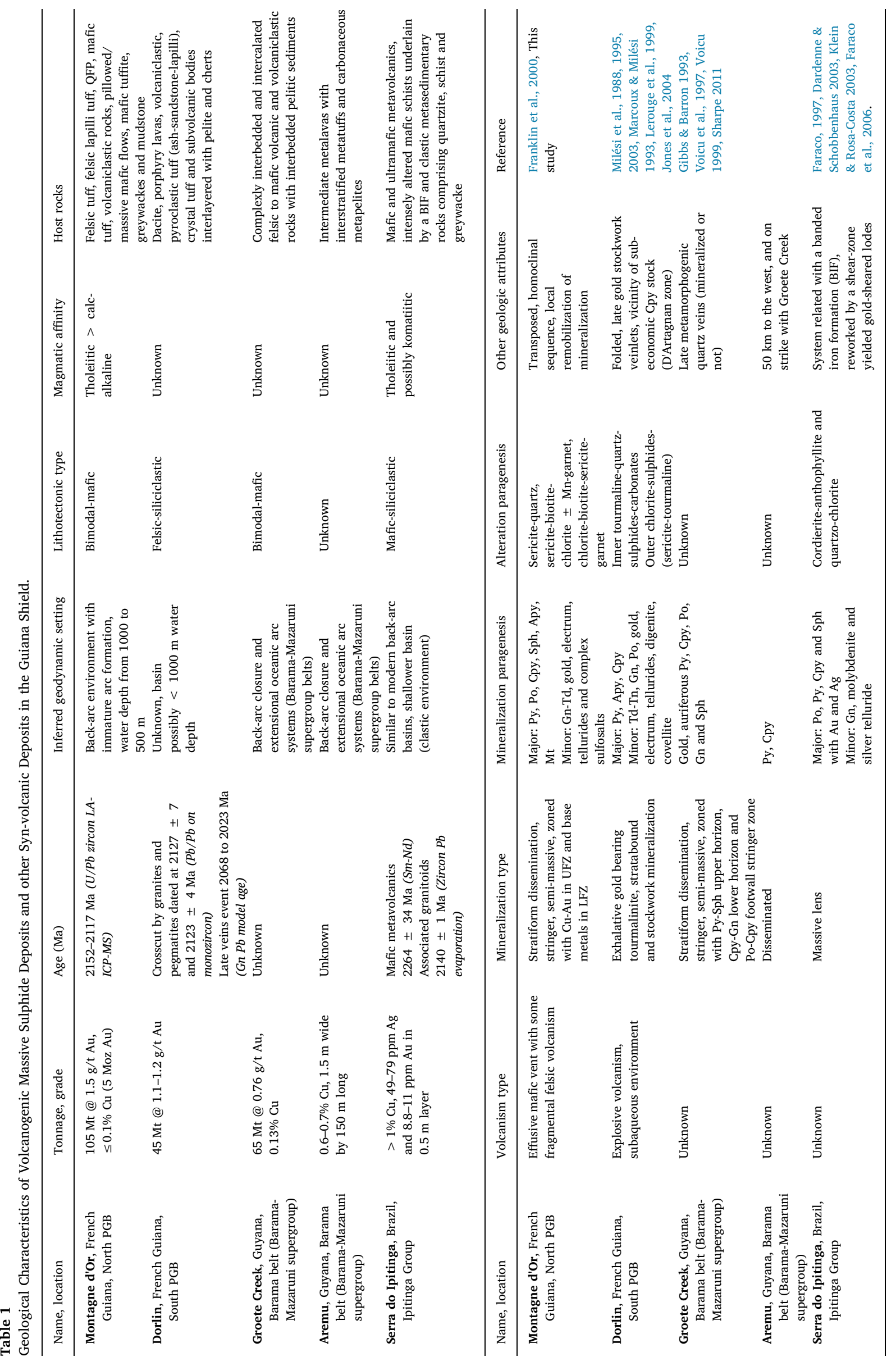


rocks at Serro do Ipitinga is an indication of shallow-water environment and/or a proximal continental landmass. Also, the mafic volcanic rocks of the Ipitinga Group, hosting the Serra do Ipitinga mineralization, yielded a Sm-Nd model age of $2264 \pm 34$ Ma (McReath and Faraco, 1997) whereas surrounding granitoids yielded an $\mathrm{Pb} / \mathrm{Pb}$ zircon age of $2140 \pm 1 \mathrm{Ma}$ (Da Rosa-Costa et al., 2003), suggesting that it is significantly older than other volcanogenic deposits of the Guiana Shield (Table 1).

Geochronological data from the Montagne d'Or suggest that the volcanic-intrusive sequence formed from ca. 2152 to ca. $2130 \mathrm{Ma}$, which is contemporaneous with calc-alkaline intrusions of the Mana river (Enjolvy, 2008) and felsic volcanism of the St-Élie area (Table 1). Age data from several intermediate-to-felsic volcanic rocks of the Paramaca Greenstone Belt (PGB) vary from 2.15 to $2.13 \mathrm{Ga}$ (Delor et al., 2003b) almost coeval with those of the Montagne d'Or. Volcanism of the central and upper parts of the PGB likely has been attributed to the formation of back-arc basin, involving immature arc volcanism and subduction (Voicu et al., 1997; Vanderhaeghe et al., 1998; Delor et al., 2003b). However, it is possible that some of these arc volcanoes were more mature and emergent, which would explain why parts of PGB are more felsic, and enriched in calc-alkaline rocks as compared to mafic back-arc ocean-floor tholeiites. As argued by Kroonenberg et al. (2016), the recycling of mature and emergent arc massifs would then account for the significant contribution of volcanic detritus in the Paramaca sedimentary rocks and the lower part of the Armina Formation.

Such geodynamic environment occurring in the Guiana Shield seems to be similar to the southern West African Craton of the Baoule Mossi domain which is considered as a complex arc-back-arc environment accompanied by the deposition of deep-water sedimentary units during 2160 to 2140 Ma (Grenholm et al., 2019). Moreover, the rare base metal deposits occur at this time, such the Perkoa Zn-Ag VMS and the Nabénia-Tiébélé Zn VMS deposits in Burkina Faso. Volcanic rocks are related to an intra-oceanic subduction setting for Perkoa (Schwartz and Melcher, 2003) and to tholeiitic rhyolites for Nabénia-Tiébélé (Ilboudo et al., 2017). A 2175 Ma quartz-diorite crosscutting the VMS mineralization at Perkoa indicates that this deposit is older (Davis, 2001 in Schwartz and Melcher, 2003). The Nabénia-Tiébélé VMS district has been dated at ca. $2156 \mathrm{Ma}$, which is significantly younger than Perkoa (Kaboré, 2004 in Ilboudo et al., 2017).

In the regional tectonic events, the sub-vertical lineation, vertical movement, metamorphism with chlorite-biotite-andalusite blastesis and N-S to NNW-SSE far-field stress that characterised the D1 event of the Montagne d'Or sequence are consistent with the regional D1 tectonic event occurring in French Guiana as defined by Delor et al. (2003a,b). However, the age range $2150-2130$ Ma of the D1 tectonic event of Delor et al. (2003a,b) is older than the youngest deformed dated rocks at Montagne d'Or (i.e. $2117 \mathrm{Ma}$ ). Dikes of diabase cut all lithologies and post-date the S1 schistosity. This oblique NE-WSW trending diabase dike swarm reveals lens and sigmoidal shapes. These diabase dikes are attributed to the formation of extensional fractures. Several elements support a deformation event that controlled and affected them during or slightly after their emplacement. If such a hypothesis is correct, a ENE-WSW far-field stress is related to this secondary deformation event (D2) but without cleavage or schistosity formation. The regional D2a tectonic event has NE-SW far-field stress and is related to a granitic suite and gabbro intrusions (Delor et al., 2003a,b). It is consistent with the proposed D2 event at Montagne d'Or. Late veins in diabase dikes suggest at least a third deformation event occurring in more brittle condition with local sulphides and gold remobilization.

\section{Conclusions}

The Montagne d'Or deposit is a bimodal-mafic type VMS deposit hosted by a south-facing highly-strained volcanic sequence of the
Paramaca Greenstone Belt. Volcanic and intrusive rocks hosting the mineralization yielded U-Pb zircon ages of 2152-to-2130 Ma and a crosscutting porphyry intrusion constrains the minimum age of the VMS at 2117.6 $\pm 5.1 \mathrm{Ma}$. Bimodal magmatic rocks hosting the mineralization were formed during the coeval activity of at least two volcanic centers, a mafic volcanic event that produced massive and pillowed basalt flows in the eastern part of the Montagne d'Or property, and a westward felsic event that produced a bedded series of felsic volcaniclastic rocks crosscut by QFP intrusions. The two volcanic to intrusive centers worked by sequential magmatic pulses, explaining the nature of the interbedded/interdigitated volcanic sequences. A tuffite horizon within the volcanic sequence marks a pause in the bimodal volcanism. The VMS mineralization of the Montagne d'Or deposit originated through replacement processes in felsic volcaniclastic rocks and thin horizons of mafic tuff between the pillowed and massive mafic flows of the bimodal sequence. Underneath the bimodal volcanic sequence, a Lower unit consists of mafic volcanic and reworked volcaniclastic rocks that constitutes the footwall of the Montagne d'Or deposit. The upper sedimentary and volcanic unit overlies the bimodal formation and mineralized horizons and forms the hangingwall. The Montagne d'Or sequence formed in a marine environment with an inferred water depth ranging between 500 and $1000 \mathrm{~m}$. Coexisting tholeiitic and calc-alkaline volcanic rocks suggest that it formed in a backarc environment at ca. 2152-2130 Ma. The West African Craton counterpart presents such geodynamic environment during that time period in the Baoulé-Mossi domain which also hosting the two base metals VMS deposits discovered in this area. The principal deformational event that strongly affects and transposes the Montagne d'Or sequence is attributed to the end of D1 regional event at or slightly younger than 2117 Ma. Diabase dikes postdate that deformational event, their emplacement can be attributed to the formation of extensional fractures during a second, more discrete event of deformation. The Paramaca Greenstone Belt hosts several other potential VMS systems of in northern Guiana Shield, some of them with geological features and sulphide mineralization very similar to the Montagne d'Or sequence, i.e. gold enrichment, inferred back-arc setting, sedimentary cover rocks. However, the Montagne d'Or deposit is unique by its subsea floor replacement process. Montagne d'Or, with its sulphide-rich mineralization, clearly overprinted by a regional deformation event, differs from the abundant orogenic gold deposits in the northern Guiana Shield. In addition, the Montagne d'Or deposit is currently the oldest one known in the Guiana Shield.

\section{Declaration of Competing Interest}

The authors declare that they have no known competing financial interests or personal relationships that could have appeared to influence the work reported in this paper.

\section{Acknowledgements}

This research is a part of Ph.D. project and has been supported by funding from the "Fonds de Recherche du Québec - Nature et Technologies" (FRQNT) to J.G., and from the Natural Sciences and Engineering Research Council Of Canada (NSERC) to A.T. (PG105669) and M.J. The authors thank Columbus Gold Corporation and "Compagnie minière Montagne d'Or" for its financial and technical support, and are especially grateful to the exploration team in French Guiana for useful discussions and advice in the field, especially G. Courtois, M. Boudrie, Y. Da Rocha, B. Fradet, L. Bouvier, T. de Cathelineau and C. Thibault Boyer. Thanks are also due to members of the Geotop U/Pb laboratory, especially N. Revelli, M. Perrot, J. David, J. Gogo, A. Poirier and A. Rouleau. Marc Bardoux and an anonymous reviewer are acknowledged for their careful reviews which have improved this manuscript substantially. The Editorial Board is thanked for its editorial work. 


\section{Appendix A}

Table A1

The analytical methodology applied by the Geotop laboratory for the dated samples.

Laboratory \& Sample Preparation

\begin{tabular}{ll}
\hline Laboratory name & Geotop; Université du Québec à Montréal \\
Sample type/mineral & Zircon \\
Sample preparation & Conventional mineral separation, 1 in. resin mount, $1 \mu \mathrm{m}$ polish to finish and thin section \\
Imaging & Centorus CL imager on a Hitachi S3400N SEM
\end{tabular}

Laser ablation system

$\begin{array}{ll}\text { Make, Model \& type } & \text { Photon-Machines G2 } \\ \text { Ablation cell } & \text { Helix two-volume cell } \\ \text { Laser wavelength (nm) } & 193 \mathrm{~nm} \\ \text { Pulse width }(\mathrm{ns}) & 4 \mathrm{~ns} \\ \text { Fluence }\left(\mathrm{J} . \mathrm{cm}^{-2}\right) & 3 \mathrm{~J} / \mathrm{cm}^{2} \\ \text { Repetition rate }(\mathrm{Hz}) & 5 \mathrm{~Hz} \\ \text { Ablation duration (secs) } & 30 \mathrm{secs} \\ \text { Ablation pit depth / ablation rate } & \text { Not available } \\ \text { Spot diameter }(\mu \mathrm{m}) \text { nominal/actual } & 30 \mu \mathrm{m} \\ \text { Sampling mode / pattern } & \text { Static spot ablation } \\ \text { Carrier gas } & 100 \% \text { He in ablation cell, Ar make-up gas combined using a Y-piece } 35 \% \text { along the sample transport line to the torch. } \\ & \text { Squid smoothing device. } \\ \text { Cell carrier gas flow }(\mathrm{l} / \mathrm{min}) & 0.71 / \mathrm{min} \text { in first volume cello.5 l/min in second volume cell }\end{array}$

ICP-MS Instrument

Make, Model \& type

Sample introduction

RF power (W)

Make-up gas flow $(1 / \mathrm{min})$

Detection system

Masses measured

Integration time per peak/dwell times ( $\mu$ s)

Total integration time per output datapoint (secs)

'Sensitivity' as useful yield (\%, element)

IC Dead time (ns)

Data Processing

\section{Gas blank}

Calibration strategy

Reference Material info

Data processing package used / Correction for LIEF

Mass discrimination

Common- $\mathrm{Pb}$ correction, composition and uncertainty

Uncertainty level \& propagation

Quality control / Validation

Other information
$\mathrm{Nu}$ Instruments, Nu Attom HR-ICP-MS

Ablation aerosol

$1300 \mathrm{~W}$

Ar (ca. 0.75 l/min, optimized daily)

Ion counter; full size discrete dynode type

202, 204, 206, 207, 208, 232, 235, 238

500 us per isotope, 20 sweeps per cycle

$0.1 \mathrm{~s}$

0.4\%U (NIST $610=500$ ppm, \#atoms sampled: 500 ppm*85 $\mu \mathrm{m}^{*} 5 \mathrm{~Hz}^{* 3} \mathrm{~J} / \mathrm{cm}^{2}:>25 \mathrm{Mcps}{ }^{238} \mathrm{U}$ )

$12 \mathrm{~ns}$

\author{
$30 \mathrm{~s}$ on-peak zero subtracted \\ 91,500 used as primary reference material, in-house secondary \\ 91,500 (Wiedenbeck et al. 1995) \\ $\mathrm{Nu}$ Instruments NuAttom TRA software and Iolite (Paton et al., 2011) for data normalization, uncertainty \\ propagation and age calculation. LIEF correction assumes reference material and samples behave identically. \\ Down-hole correction and standard bracketing (Iolite) \\ No common-Pb correction applied to the data. \\ Ages are quoted at $2 s$ absolute, error propagation is by Iolite. \\ In house secondary standard \\ Zircon dating using laser ablation are limited to uncertainties of no better than $3 \%(2 \sigma)$ of the determined age due to \\ matrix and/or ablation related effects (Klotzli et al., 2009).
}

\section{Appendix B. Supplementary data}

Supplementary data to this article can be found online at https://doi.org/10.1016/j.precamres.2019.105551.

\section{References}

Allen, R.L., Weihed, P., Svenson, S.-A., 1996b. Setting of Zn-Cu-Au-Ag massive sulfide deposits in the evolution and facies architecture of a 1.9 Ga marine volcanic arc Skellefte District, Sweden. Econ. Geol. 91, 1022-1053.

Allen, R.L., Lundstrom, I., Ripa, M., Christofferson, H., 1996a. Facies analysis of a 1.9 Ga, continental margin, back-arc, felsic caldera province with diverse $\mathrm{Zn}-\mathrm{Pb}-\mathrm{Ag}$ - $\mathrm{Cu}-\mathrm{Au})$ sulfide and Fe oxide deposits, Bergslagen region, Sweden. Econ. Geol. 91, 979-1008.

Avelar, V.d., Lafon, J.-M., Delor, C., Guerrot, C., Lahondère, D., 2003. Archean crustal remnants in the easternmost part of the Guiana Shield: $\mathrm{Pb}-\mathrm{Pb}$ and $\mathrm{Sm}-\mathrm{Nd}$ geochronological evidence for Mesoarchean versus Neoarchean signatures. Géologie de la France 2-3-4, 83-99.

Bekker, A., Slack, J.F., Planavsky, N., Krapez, B., Hofmann, A., Konhauser, K.O., Rouxel, O.J., 2010. Iron formation: the sedimentary product of a complex interplay among mantle, tectonic, oceanic, and biospheric processes. Econ. Geol. 105, 467-508.

Bleeker, W., Parrish, R.R., 1996. Stratigraphy and U-Pb zircon geochronology of Kidd Creek: implications for the formation of giant volcanogenic massive sulphide deposits and the tectonic history of the Abitibi greenstone belt. Can. J. Earth Sci. 33, 1213-1231.

Bout, J.P., Millo, L., Taquet, B., Voglet, G., 1998. Projet Paul Isnard - Projet Eau Blanche Secteur de la Montagne d'Or - Rapport d'étape $n^{\circ} 4$. Unpublished Technical Report for Guyanor Ressources, p. 50.

Bosma, W., Kroonenberg, S.B., Maas, K., de Roever, E.W.F., 1983. Igneous and metamorphic complexes of the Guiana Shield in Suriname. Geologie Mijnbouw 62, 241-254.

Carey, R., Soule, S.A., Manga, M., White, J.D., McPhie, J., Wysoczanski, R., Jutzeler, M., Tani, K., Yoerger, D., Fornari, D., 2018. The largest deep-ocean silicic volcanic eruption of the past century. Sci. Adv. 4, e1701121.

Channer, D.M.D., Anderson, P.F.N., 2000. Volcanogenic massive sulphide occurrences and potential in Venezuela, with emphasis on the Guiana Shield. In: Sherlock, R., Logan, M.A.V. (Eds.), VMS Deposits of Latin America, Geological Association of Canada, Mineral Deposits Division. Special Publication, pp. 293-314.

Choubert, B., 1974. Le Precambrien des Guyanes. Mem. BRGM 81, 213.

Corfu, F., Hanchar, J.M., Hoskin, P.W., Kinny, P., 2003. Atlas of zircon textures. Rev. Mineral. Geochem. 53, 469-500. 
Da Rosa-Costa, L.T., Ricci, P., Lafon, J.-M., Vasquez, M., Carvalho, J., Klein, E., Macambira, E., 2003. Geology and geochronology of Archean and Paleoproterozoic domains of the southeastern Amapá and northwestern Pará, Brazil-southeastern Guiana Shield. Géol. Fr. 2-3-4, 101-120.

Da Rosa-Costa, L.T., Lafon, J.-M., Cocherie, A., Delor, C., 2008. Electron microprobe U Th- $\mathrm{Pb}$ monazite dating of the Transamazonian metamorphic overprint on Archean rocks from the Amapá Block, southeastern Guiana Shield, Northern Brazil. J. S. Am. Earth Sci. 26, 445-462.

Daoust, C., 2016. Caractérisation stratigraphique, structurale et géochimique du district minéralisé de Rosebel (Suriname) dans le cadre de l'évolution géodynamique du Bouclier Guyanais. PhD Thesis. Université du Québec à Montréal, pp. 330.

Daoust, C., Voicu, G., Brisson, H., Gauthier, M., 2011. Geological setting of the Paleoproterozoic Rosebel gold district, Guiana Shield, Suriname. J. S. Am. Earth Sci. $32,222-245$.

Dardenne, M., Schobbenhaus, C., 2003. 2-3-4 In: Metallogeny of the Guiana Shield. Géologie de la France, pp. 291-319.

De Roever, E.W.F., Lafon, J.-M., Delor, C., Cocherie, A., Rossi, P., Guerrot, C., Potrel, A., 2003. The Bakhuis ultrahigh-temperature granulite belt (Suriname): I. petrological and geochronological evidence for a counterclockwise P-T path at 2.07-2.05 Ga. Géol. Fr. 2-3-4, 175-205.

de Ronde, C.E., Hannington, M., Stoffers, P., Wright, I., Ditchburn, R., Reyes, A., Baker, E., Massoth, G., Lupton, J., Walker, S., 2005. Evolution of a submarine magmatic-hydrothermal system: brothers volcano, southern Kermadec arc, New Zealand. Econ. Geol. 100, 1097-1133.

Deckart, K., Féraud, G., Bertrand, H., 1997. Age of Jurassic continental tholeiites of French Guyana, Surinam and Guinea: implications for the initial opening of the Central Atlantic Ocean. Earth Planet. Sci. Lett. 150, 205-220.

Delor, C., Lahondère, D., Egal, E., Lafon, J.-M., Cocherie, A., Guerrot, C., Rossi, P., Truffert, C., Théveniaut, H., Phillips, D., Avelar, V.G.d., 2003b. 2-3-4 In: Transamazonian crustal growth and reworking as revealed by the 1:500000 scale geological map of French Guiana. Géologie de la France, pp. 5-57.

Delor, C., de Roever, E.W.F., Lafon, J.-M., Lahondère, D., Rossi, P., Cocherie, A., Guerrot, C., Potrel, A., 2003a. The Bakhuis ultrahigh-temperature granulite belt (Suriname): II. Implications for late Transamazonian crustal stretching in a revised. Géol. Fr. 2-34, 207-230.

Delor, C., Lahondère, D., Egal, E., Marteau, P., 2001. Carte géologique de la Guyane Française au 1: 500 000, BRGM, 2 ed.

Dubé, B., Gosselin, P., Mercier-Langevin, P., Hannington, M., Galley, A., 2007. Gold-rich volcanogenic massive sulphide deposits. Mineral Deposits of Canada: A Synthesis of Major Deposit-Types, District Metallogeny, the Evolution of Geological Provinces, and Exploration Methods: Geological Association of Canada, Mineral Deposits Division, Special Publication 5, 75-94.

Egal, E., Mercier, D., Itard, Y., Mounié, F., 1992. L'ouverture de bassins en pull-apart au Protérozoïque inférieur: nouveaux arguments dans le nord du craton guyanais. Comptes rendus de l'Académie des sciences. Série 2, Mécanique, Physique, Chimie, Sciences de l'univers, Sciences de la Terre 314, 1499-1506.

Enjolvy, R., 2008. Processus d'accrétion crustale et régimes thermiques dans le bouclier des Guyanes: signatures géochimiques et thermochronologiques au transamazonien (2250-1950Ma). PhD Thesis. Université Montpellier II-Sciences et Techniques du Languedoc, pp. 305.

Faraco, M., Fuzikawa, K., Ramboz, C., McReath, I., 2006. A fluid inclusion study in the hydrothermal volcanogenic sulfide and orogenic gold mineralization at the Serra do Ipitinga, Amazon, Brazil. Revista Brasileira de Geociências 36, 51-58.

Faraco, M.T.L., 1997. Evoluçao petroquimico-metalogenética das rochas e mineralizaçoes associadas à Suite Vila Nova na serra do Ipitinga (NW do Parà). Centro Geociências. UFPa, p. 245

Franklin, J., Bertoni, C., Boudrie, M., Bout, J., Costelloe, D., Lillie, F., Millo, L., Sauvage, J., 2000. The Paul Isnard gold-copper occurrence, French Guiana: the first volcanogenic massive sulphide occurrence in the Guiana Shield? In: Sherlock, R., Logan, M.A.V. (Eds.), VMS Deposits of Latin America, Geological Association of Canada, Mineral Deposits Division. Special Publication, pp. 509-542.

Franklin, J.M., Gibson, H.L., Jonasson, I.R., Galley, A.G., 2005. Volcanogenic Massive Sulfide Deposits. In: Hedenquist, J.W., Thompson, J.F.H., Goldfarb, R.J., Richards, J.P. (Eds.), Economic Geology 100th Anniversary Volume. Society of Economic Geologists, pp. 523-560.

Galley, A.G., 2003. Composite synvolcanic intrusions associated with Precambrian VMSrelated hydrothermal systems. Miner. Deposita 38, 443-473.

Gibbs, A.K., Barron, C.N., 1993. The Geology of the Guiana Shield. Oxford University Press, USA, pp. 246.

Gibson, H.L., Morton, R.L., Hudak, G.J., 1999. Submarine volcanic processes, deposits, and environments favorable for the location of volcanic-associated massive sulfide deposits. In: Barrie, C.T., Hannington, M.D. (Eds.), Volcanic Associated Massive Sulfide Deposits: Processes and Examples in Modern and Ancient Settings. Society of Economic Geologists, pp. 13-52.

Gibson, H.L., Allen, R.L., Riverin, G., Lane, T.E., 2007. The VMS model: advances and application to exploration targeting. In: Proceedings of Exploration 07: Fifth Decennial International Conference on Mineral Exploration, pp. 713-730.

Goldfarb, R.J., Bradley, D., Leach, D.L., 2010. Secular variation in economic geology. Econ. Geol. 105, 459-465.

Grenholm, M., Jessell, M., Thébaud, N., 2019. A geodynamic model for the Paleoproterozoic (ca. 2.27-1.96 Ga) Birimian Orogen of the southern West African Craton-Insights into an evolving accretionary-collisional orogenic system. Earth Sci. Rev. 192, 138-193.

Groves, D.I., Goldfarb, R.J., Robert, F., Hart, C.J., 2003. Gold deposits in metamorphic belts: overview of current understanding, outstanding problems, future research, and exploration significance. Econ. Geol. 98, 1-29.
Guiraud, J., Tremblay, A., Jébrak, M., Ross, P.-S., Lefrançois, R., 2015. Auriferous volcanogenic massive sulphide, A new type of gold deposit in the Guiana shield, Joint Assembly AGU-GAC-MAC-CGU, Montréal, Canada.

Hanski, E., 2015. Synthesis of the Geological Evolution and Metallogeny of Finland. Mineral Deposits of Finland. Elsevier, Oxford, pp. 39-71.

Hubé, D., 1997. Rapport de stage ENSG 3ème année. Unpublished MSc Thesis, ENSG, p. 36.

Huston, D.L., Relvas, J.M., Gemmell, J.B., Drieberg, S., 2011. The role of granites in volcanic-hosted massive sulphide ore-forming systems: an assessment of magmatic-hydrothermal contributions. Miner. Deposita 46, 473-507.

Ilboudo, H., Lompo, M., Wenmenga, U., Napon, S., Naba, S., Ngom, P.M., 2017. Evidence of a Volcanogenic Massive Sulfide $(\mathrm{ZnPbCuAg})$ district within the Tiébélé Birimian (Paleoproterozoic) Greenstone Belts, Southern Burkina Faso (West-Africa). J. Afr. Earth Sc. 129, 792-813.

Jones, C., Sperinck, M., Hearne, J., 2004. Yaou, Dorlin \& Paul-Isnard Projects, French Guiana: Independent Resource Estimations. RSG Global, Unpublished Technical Report for Golden Star Resources Limited, p. 100.

Klaver, M., De Roever, E.W.F., Nanne, J.A.M., Mason, P.R.D., Davies, G.R., 2015. Charnockites and UHT metamorphism in the Bakhuis Granulite Belt, western Suriname: evidence for two separate UHT events. Precambr. Res. 262, 1-19.

Klein, E.L., Rosa-Costa, L.T., 2003. Geology of quartz-vein gold deposits in the Ipitinga Auriferous District, northern Brazil, southeastern Guiana Shield. Géol. Fr. 2-3-4, 231-242.

Klein, E.L., Lafon, J.-M., Harris, C., Brito, R.S., Vaconcelos, P., 2009. Fluid inclusion and isotopic constraints on the genesis of vein-quartz gold deposits of the Ipitinga Auriferous District, SE-Guiana Shield, Brazil. Contribuições à Geologia da Amazônia 6, 15-42.

Klug, C., Cashman, K.V., 1996. Permeability development in vesiculating magmas: implications for fragmentation. Bull. Volcanol. 58, 87-100.

Kneller, B., 1995. Beyond the turbidite paradigm: physical models for deposition of turbidites and their implications for reservoir prediction. Geol. Soc., London, Spec. Public. 94, 31-49.

Kokelaar, P., 1986. Magma-water interactions in subaqueous and emergent basaltic. Bull. Volcanol. 48, 275-289.

Kroonenberg, S.B., de Roever, E.W.F., Fraga, L., Reis, N., Faraco, T., Lafon, J.-M., Cordani, U., Wong, T., 2016. Paleoproterozoic evolution of the Guiana Shield in Suriname: a revised model. Neth. J. Geosci. 95, 491-522.

Lafrance, J., Bardoux, M., Voicu, G., Stevenson, R., Machado, N., 1999. Geological and metallogenic environments of gold deposits of the Guiana Shield; a comparative study between St-Elie (French Guiana) and Omai (Guyana). Explor. Min. Geol. 8, $117-135$.

Ledru, P., Lasserre, J., Manier, E., Mercier, D., 1991. Le Proterozoique inferieur nord guyanais; revision de la lithologie, tectonique transcurrente et dynamique des bassins sedimentaires. Bulletin de la Société Géologique de France 162, 627-636.

Ledru, P., Johan, V., Milési, J.P., Tegyey, M., 1994. Markers of the last stages of the Palaeoproterozoic collision: evidence for a $2 \mathrm{Ga}$ continent involving circum-South Atlantic provinces. Precambr. Res. 69, 169-191.

Lerouge, C., Milési, J.-P., Fouillac, A.-M., 1999. The Paleoproterozoic Dorlin gold deposit, French Guiana: genetic constraints of the stable isotope geochemistry. Chem. Geol. 155, 131-149.

Marcoux, É., Milési, J.-P., 1993. Lead isotope signature of early Proterozoic ore deposits in western Africa; comparison with gold deposits in French Guiana. Econ. Geol. 88, 1862-1879.

Marot, A., 1988. Carte géologique du Sud de la Guyane à 1/500 000 et notice, BRGM

McPhie, J., Doyle, M., Allen, R.L., Allen, R., 1993. Volcanic Textures: A Guide to the Interpretation of Textures In Volcanic Rocks. CODES-University of Tasmania.

McReath, I., Faraco, M., 1997. Sm-Nd and Rb-Sr systems in part of the Vila Nova metamorphic suite, northern Brazil. In: South American Symposium on Isotope Geology, pp. 194-196.

Mercier-Langevin, P., Hannington, M.D., Dubé, B., Bécu, V., 2011. The gold content of volcanogenic massive sulfide deposits. Miner. Deposita 46, 509-539.

Milési, J.-P, Picot, J., 1995. L'Or en Guyane française: Contexte et potentiel géologiques, Rapport BRGM/RP-38517-FR, BRGM, p. 31.

Milési, J.-P., Egal, E., Ledru, P., Vernhet, Y., Thiéblemont, D., Cocherie, A., Tegyey, M., Martel-Jantin, B., Lagny, P., 1995. Les minéralisations du Nord de la Guyane française dans leur cadre géologique. Chronique de la recherche Miniere 518, 5-59.

Milési, J.-P., Lambert, A., Ledru, P., 1988. Résultats préliminaires à l'étude gîtologique et structurale de Dorlin (Guyane). Mission du 06 au 26.11.1987. Rapport BRGM 88 GUF 052 DEX, BRGM, p. 40

Milési, J.-P., Lerouge, C., Delór, C., Ledru, P., Billa, M., Cocherie, A., Egal, E., Fouillac, A., Lahondère, D., Lasserre, J., Marot, A., Martel-Jantin, B., Rossi, P., Tegyey, M., Théveniault, H., Thiéblemont, D., Vanderhaeghe, O., 2003. Gold deposits (goldbearing tourmalinites, gold-bearing conglomerates, and mesothermal lodes), markers of the geological evolution of French Guiana: geology, metallogeny, and stable-isotope constraints. 2-3-4. Géologie de la France, pp. 257-290.

Millo, L., 1999. Projet Paul Isnard - Projet Eau Blanche - Rapport d'étape n5. Unpublished Technical Report for Guyanor Resources, p. 80.

Naipal, R., Kroonenberg, S.B., 2016. Provenance signals in metaturbidites of the Paleoproterozoic greenstone belt of the Guiana Shield in Suriname. Neth. J. Geosci. 95, 467-489.

Nomade, S., Knight, K., Beutel, E., Renne, P., Verati, C., Féraud, G., Marzoli, A., Youbi, N., Bertrand, H., 2007. Chronology of the Central Atlantic Magmatic Province: implications for the Central Atlantic rifting processes and the Triassic-Jurassic biotic crisis. Palaeogeogr. Palaeoclimatol. Palaeoecol. 244, 326-344.

Pehrsson, S., Gibson, H.L., Gilmore, K., 2016. A special issue on volcanogenic massive sulfide deposits of the trans-hudson orogen: preface. Econ. Geol. 111, 803-816. 
Piercey, S.J., 2011. The setting, style, and role of magmatism in the formation of volcanogenic massive sulfide deposits. Miner. Deposita 46, 449-471.

Piercey, S.J., Peter, J.M., Mortensen, J.K., Paradis, S., Murphy, D.C., Tucker, T.L., 2008. Petrology and $\mathrm{U}-\mathrm{Pb}$ geochronology of footwall porphyritic rhyolites from the Wolverine volcanogenic massive sulfide deposit, Yukon, Canada: implications for the genesis of massive sulfide deposits in continental margin environments. Econ. Geol. 103, 5-33.

Poulsen, K.H., 2000. Geological classification of Canadian gold deposits. Bull. Geol. Survey Canada 540, 1-106.

Pupin, J., 1980. Zircon and granite petrology. Contrib. Miner. Petrol. 73, 207-220.

Ross, P.-S., 2014. In: Examination of drill cores and lithogeochemical data from the Montagne d'Or deposit, Paul Isnard project, French Guiana. Unpublished Report for Columbus Gold Corp. \& SOTRAPMAG SAS, pp. 77.

Schwartz, M., Melcher, F., 2003. The Perkoa zinc deposit, Burkina Faso. Econ. Geol. 98, 1463-1485.

Sharpe, G.C., 2011. Unpublished NI 43-101 Technical Report on the Groete Creek and Georgetown West Properties Guyana. MCIM, Consulting Mineral Exploration Geologist. Gold Port Resources Ltd., pp. 106.

Sidder, G.B., Garcia, A., Stoeser, J., 1995. Geology and mineral deposits of the Venezuelan Guayana Shield. USGPO, p. 320.

Sullivan, W.A., 2013. L tectonites. J. Struct. Geol. 50, 161-175.

Tassinari, C.C., Munhá, J.M., Teixeira, W., Palácios, T., Nutman, A.P., Sosa, C., Santos, A.P., Calado, B.O., 2004. The Imataca Complex, NW Amazonian Craton, Venezuela: crustal evolution and integration of geochronological and petrological cooling histories. Episodes-Newsmagazine of the International Union of Geological Sciences, pp. 3-12.

Tedeschi, M., Hagemann, S.G., Davis, J., 2018. The Karouni Gold Deposit, Guyana, South
America: part I. Stratigraphic Setting and Structural Controls on Mineralization. Econ. Geol. 113, 1679-1704.

Thomas, S.J., 2014. Report on Processing and Analysis of a VTEM EM \& Magnetic Survey Paul Isnard project French Guiana. Unpublished Technical Report for Columbus Gold Corp Condor Consulting Inc, pp. 76.

Vanderhaeghe, O., Ledru, P., Thiéblemont, D., Egal, E., Cocherie, A., Tegyey, M., Milési, J.-P., 1998. Contrasting mechanism of crustal growth: Geodynamic evolution of the Paleoproterozoic granite-greenstone belts of French Guiana. Precambr. Res. 92, 165-193.

Voicu, G., 1999. The Geology, Geochemistry and Metallogeny of the Omai Gold Deposit, Guyana, South America. PhD Thesis. Université du Québec à Montréal, pp. 271.

Voicu, G., Bardoux, M., Harnois, L., Crepeau, R., 1997. Lithological and geochemical features of igneous and sedimentary rocks at the Omai gold mine, Guyana, South America. Explor. Min. Geol. 2, 153-170.

Voicu, G., Bardoux, M., Stevenson, R., 2001. Lithostratigraphy, geochronology and gold metallogeny in the northern Guiana Shield, South America: a review. Ore Geol. Rev. $18,211-236$.

Walker, R.G., 1967. Turbidite sedimentary structures and their relationship to proximal and distal depositional environments. J. Sediment. Res. 37, 25-43.

Walker, G.P., 1989. Gravitational (density) controls on volcanism, magma chambers and intrusions. Aust. J. Earth Sci. 36, 149-165.

White, J.D.L., 2000. Subaqueous eruption-fed density currents and their deposits. Precambr. Res. 101, 87-109.

White, J.D.L., Houghton, B.F., 2006. Primary volcaniclastic rocks. Geology 34, 677-680.

Wright, I., Gamble, J., 1999. Southern Kermadec submarine caldera arc volcanoes (SW Pacific): caldera formation by effusive and pyroclastic eruption. Mar. Geol. 161, 207-227. 